\title{
Geology of the Nine Canyon Map Area
}

M. G. Jones

R. D. Landon

September 1978

Prepared for the United States

Department of Energy

Under Contract EY-77-C-06-1030

Rockwell International

Rockwell Hanford Operations

Energy Systems Group

Richland, WA 99352 


\section{DISCLAIMER}

This report was prepared as an account of work sponsored by an agency of the United States Government. Neither the United States Government nor any agency Thereof, nor any of their employees, makes any warranty, express or implied, or assumes any legal liability or responsibility for the accuracy, completeness, or usefulness of any information, apparatus, product, or process disclosed, or represents that its use would not infringe privately owned rights. Reference herein to any specific commercial product, process, or service by trade name, trademark, manufacturer, or otherwise does not necessarily constitute or imply its endorsement, recommendation, or favoring by the United States Government or any agency thereof. The views and opinions of authors expressed herein do not necessarily state or reflect those of the United States Government or any agency thereof. 


\section{DISCLAIMER}

Portions of this document may be illegible in electronic image products. Images are produced from the best available original document. 


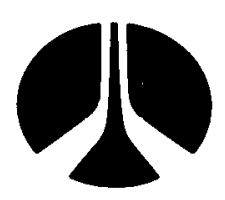

\title{
Rockwell International \\ Rockwell Hanford Operations \\ Energy Systems Group \\ Richland, WA 99352
}

\author{
PREPARED FOR THE UNITED STATES DEPARTMENT OF ENERGY \\ UNDER CONTRACT EY-77-C-06-1030
}

\section{PRELIMINARY REPORT}

This Report contains information of a prcliminary nature. It is subject to revision or currection ând thèretore does not represent a final Report. It was prepared primarilv for internal use with. in The Rnckwell Hanford Operations. Any expressed views and opinions are those of the Author and not necessarily of the Company.

\section{NOTICE}

This Report was prepared as an account of work sponsored by the United States Government. Neither the United States nor the United States Department of Energy, nor any of their Employees, nor any of their Contractors, Subcontractors, or their Employees, makes any warranty, express or implied, or assumes any legal liability or responsibility for the accuracy, com. plêteness, or usetulness of any information, apparatus, product or process disclosed, or represents that its use would not infringe privately owned rights. 
M. G. Jones

R. D. Landon

Basalt Geosciences Unit Research Department

for

Basalt Waste Isolation Program

This report was prepared as an account of work sponsored by the United States Government. Neither the United States nor the United States Department of Energy, nor any of their employees, nor any of their contractors, subcontractors, or their employees, makes any warranty, express or implied, of assumes any legal liability or responsibility for the accuracy, completeness or usefulness of any information, apparatus, product or process discrinsed, ar represents that its use would not infringe privately owned rights.

September 1978

Rockwell International

Rockwell Hanford Operations

Energy Systems Group

Richland, Washington 99352 
The basalt stratigraphy and stmucture of a 175-square kilometer area (the Nine Canyon Map Area) along the southerm margin of the Pasco Basin have been studied to help assess the feasibility of a. nuclear waste terminal storage facility. Detailed mapping shows that uplift of the Horse Heaven Hills began prior to extmusion of the Priest Rapids Member of the Wanapum Bacalt, Columbia River Basalt Group. Both the Pomona and the Elephant Mountain members (Saddle Mountains Basatt, Columitiai River Basalt Group) are widespread throughout the basin, but thin considerably along the Horse Heaven Hilis in the vicinity of Wallula Gap. The Ice Harbor Member is present only along the northem margin of the map area and possibly occupies a paleo-channel. The Rattlesnake HillsWallula Cap Lineament trends north $60^{\circ}$ degrees west and intersects the older Horse Heaven Hills anticline in Wallula Gap. Four faults. of short length and small vertical displacement are located along this stmucture. Within the map areu, the irleerlsily of folding increases, and the style of faulting changes from normal to reverse with proximity to the Walzula, Gap area.: No evidence for quaternary deformation was found.

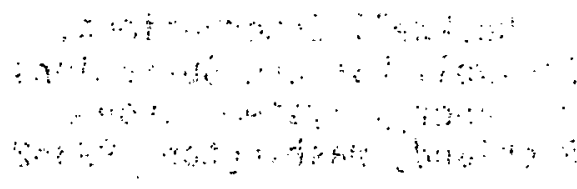


INTRODUCTION

PURPOSE $\because: 6$

LOCATION AND PHYSICAL CHARACTERISTICS $\because: \quad: \quad 6$

DIVISION OF WORK AND RESPONSIBILITY _. 6

METHODS OF INVESTIGATION 9

PREVIOUS WORK $\quad 9$

REGIONAL GEOLOGIC SETTING : 12

ACKNOWLEDGMENTS $: \cdots: 13$

STRATIGRAPHY

INTRODUCTION

WANAPUM BASALT $\quad 15$

FRENCHMAN SPRINGS MEMBER $\quad 15$

PRIEST RAPIDS MEMBER $\quad 15$

SADDLE MOUNTAINS BASALT $\cdot 17$

UMATILLA MEMBER $\quad \cdot \quad \cdot \quad 17$

POMONA MEMBER $\quad \cdot \quad 19$

$\begin{array}{lr}\text { ELEPHANT MOUNTAIN MEMBER } & 19\end{array}$

ICE HARBOR MEMBER $\cdots \cdot \cdot \cdot 28$

ELLENSBURG FORMATION $\quad 28$

PRIEST RAPIDS INTERBED $\quad \therefore \quad 28$

SELAH INTERBED $\quad 30$

RATTLESNAKE RIDGE INTERBED $\quad 30$

LEVY INTERBED $\quad 30$

PLIOCENE SEDIMENTS $\quad 30$

PLIO-PLEISTOCENE SEDIMENTS $\quad 31$

THE HANFORD FORMATION 31

STRUCTURE $\quad \cdots \cdots+31$

GENERAL $\quad 31$

JUMP-OFF-JOE ANTICLINE 32

WALLULA GAP FAULT 32

RATTLESNAKE HILLS-WALLULA GAP LINEAMENT.

THE LAST RATTLE. 37

$\begin{array}{ll}\text { THE BUTTE } & 37\end{array}$ 
Table of Contents (continued):

Page

GAME FARM HILL 43

PIPELINE HILL 43

BASALT HILL 45

CONCLUSIONS 45

BIBLIOGRAPHY 47

DI STRIBUTION 48

APPENDIX--MEASURED SECTION NUMBER 1: THE BUTTE 51

\section{LIST OF FIGURES}

FIGURE 1 GENERAL LOCATION MAP OF THE PASCO BASIN AND VICINITY

FIGURE 2 LOCATION MAP OF THE NINE CANYON MAP AREA AND VICINITY

FIGURE 3-A SAMPLE LOCATION MAP OF THE PASCO 15-MINUTE QUADRANGLE

FIGURE 3-B SAMPLE LOCATION MAP OF THE WALLULA 7.5-MINUTE QUADRANGLE

:FIGURE 4

PASCO BASIN STRATIGRAPHIC NOMENCLATURE

FIGURE 5 HIGHLY WEATHERED PRIEST RAPIDS MEMBER, ZINTEL CANYON

FIGURE 6 TYPICAL UMATILLA MEMBER OUTCROP, THE BUTTE

FIGURE 7 TYPICAL POMONA MEMBER OUTCROP, GAME FARM HILL

FIGURE 8 SECOND PRIEST RAPIDS FLOW OVERLYING THE PRIEST RAPIDS INTERBED 
Table of Contents (continued)

Page

FIGURE 9 LOCATION MAP OF MAGNETIC PROFILES

IN ZINTEL CANYON

FIGURE 10 TOTAL FIELD OF PROFILE. 1

VERSUS KNOWN GEOLOGY

FIGURE 11 VERTICAL GRADIENT OF PROFILE 1

VERSUS KNOWN GEOLOGY

FIGURE 12 PROFILE 2 IN ZINTEL CANYON

TOTAL MAGNETIC FIELD AND VERTICAL GRADIENT

FIGURE 13-A STRUCTURE AND, LOCATION MAP - PASCO 15-MINUTE QUADRANGLE :

FIGURE 13-B STRUCTURE AND LOCATION MAP - WALLULA 7.5-MINUTE QUADRANGLE

FIGURE 14 FINLEY QUARRY - THE BUTTE, CALICHE-CEMENTED

FAULT BRECCIA

FIGURE A-1 MEASURED SECTION - THE BUTTE

\section{LIST OF TABLES}

TABLE I X-RAY FLUORESCENCE ANALYSIS

TABLE II SEMI-QUANTITATIVE ENERGY DISPERSIVE $X$-RAY

\section{LIST OF PLATES}

PLATES 1-5 PRELIMINARY GEOLOGIC MAPS OF THE NINE CANYON VICINITY

In Pocket

PLATE 6 STRUCTURE CROSS SECTIONS-

NINE CANYON MAP AREA

In Pocket 


\section{INTRODUCTION}

\section{PURPOSE}

The U. S. Department of Energy, through the Basalt Waste Isolation Program within Rockwell Hanford Operations, is investigating the feasibility of terminal storage of radioactive nuclear wastes in deep caverns constructed in Columbia River Basalt. This report represents a portion of the geological work conducted during fiscal year 1978 to assess the geological conditions in the Pasco Basin where most of the effort is now concentrated.

The objective of the geological work in the Nine Canyon Map Area was to describe and map, at a scale of 1:24,000, the strattgraphic units and geologic structures which form the southern end of the Pasco Bas in (Figure 1). Those geologic features in the map area that might relate to hydrologic conditions and tectonic stability of the Pasco Basin were emphasized during: mapping. These included stratigraphic relationships of the Columbia River Basalt, the location of faults, folds, and fracture zones, plus landslides and geomorphologic features.

\section{LOCATION AND PHYSICAL CHARACTERISTICS}

The Nine Canyon Map Area, about 175 square kilometers, lies south of the city of Kennewick in south-central Washington (Figure 2) and borders the southern margin of the Pasco. Basin. The Columbia River flows southeast along the northern boundary of the map area, and then turns to the south through Wallula Gap bordering the map area on two sides (see Figure 1). The terrain varies from low rolling hills to fairly steep bluffs, relief is nowhere more than 350 meters. Although most of the land is under cultivation (wheat primarily) small portions are still used as range land and along the northern margin suburban developments are expanding into the area.

\section{DIVISION OF WORK AND RESPONSIBILITY}

Mr. R. D. Landon was responsible for mapping along the north flank of the Horse Heaven Hills and Game Farm Hill. Ms. M. G. Jones was responsible for Basalt Hill, Pipeline Hill, The Butte, and The Last Rattle. The responsibility for the remaining area mapped was shared. 


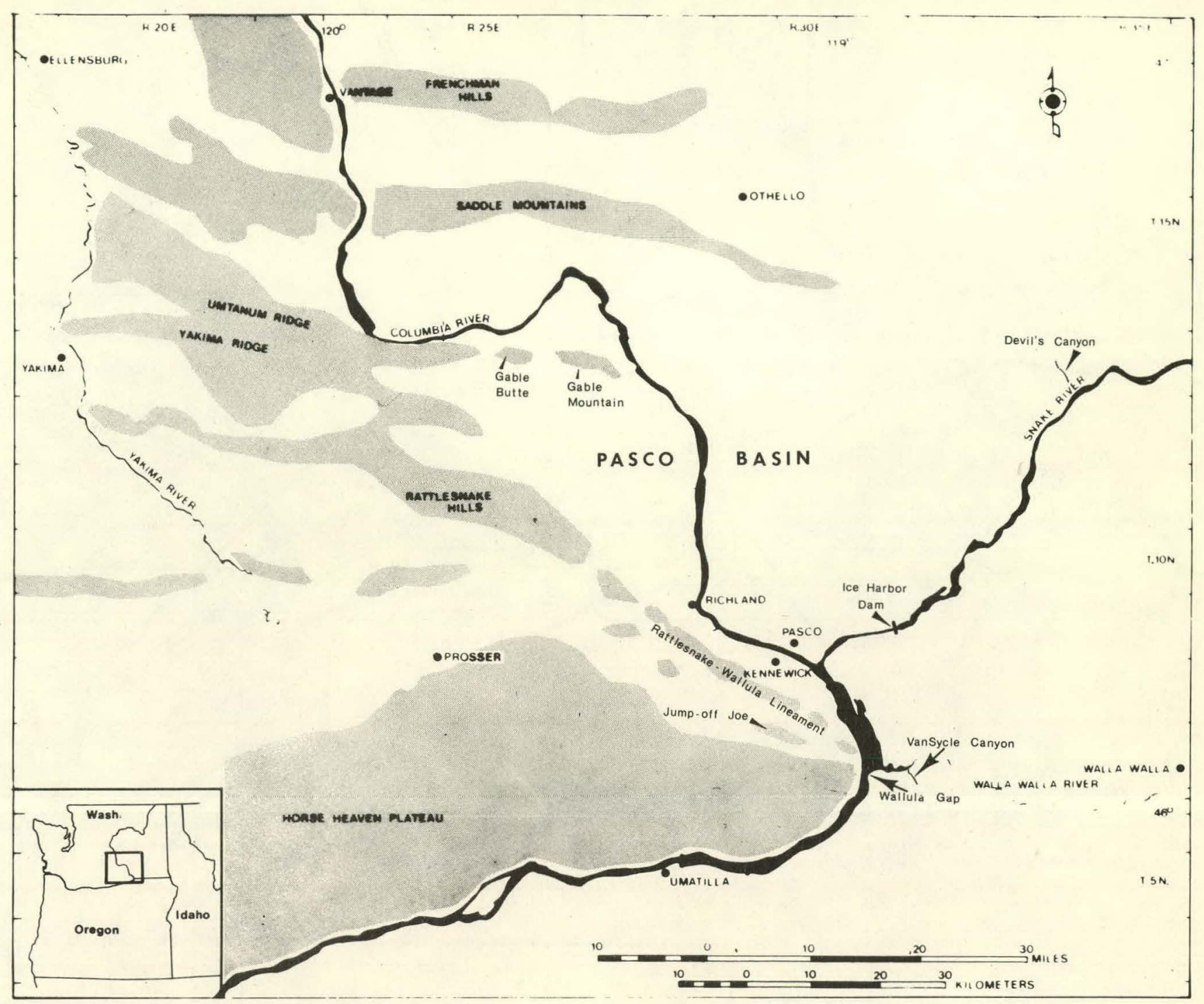

FIGURE 1

GENERAL LOCATION MAP OF THE PASCO BASIN AND VICINITY 


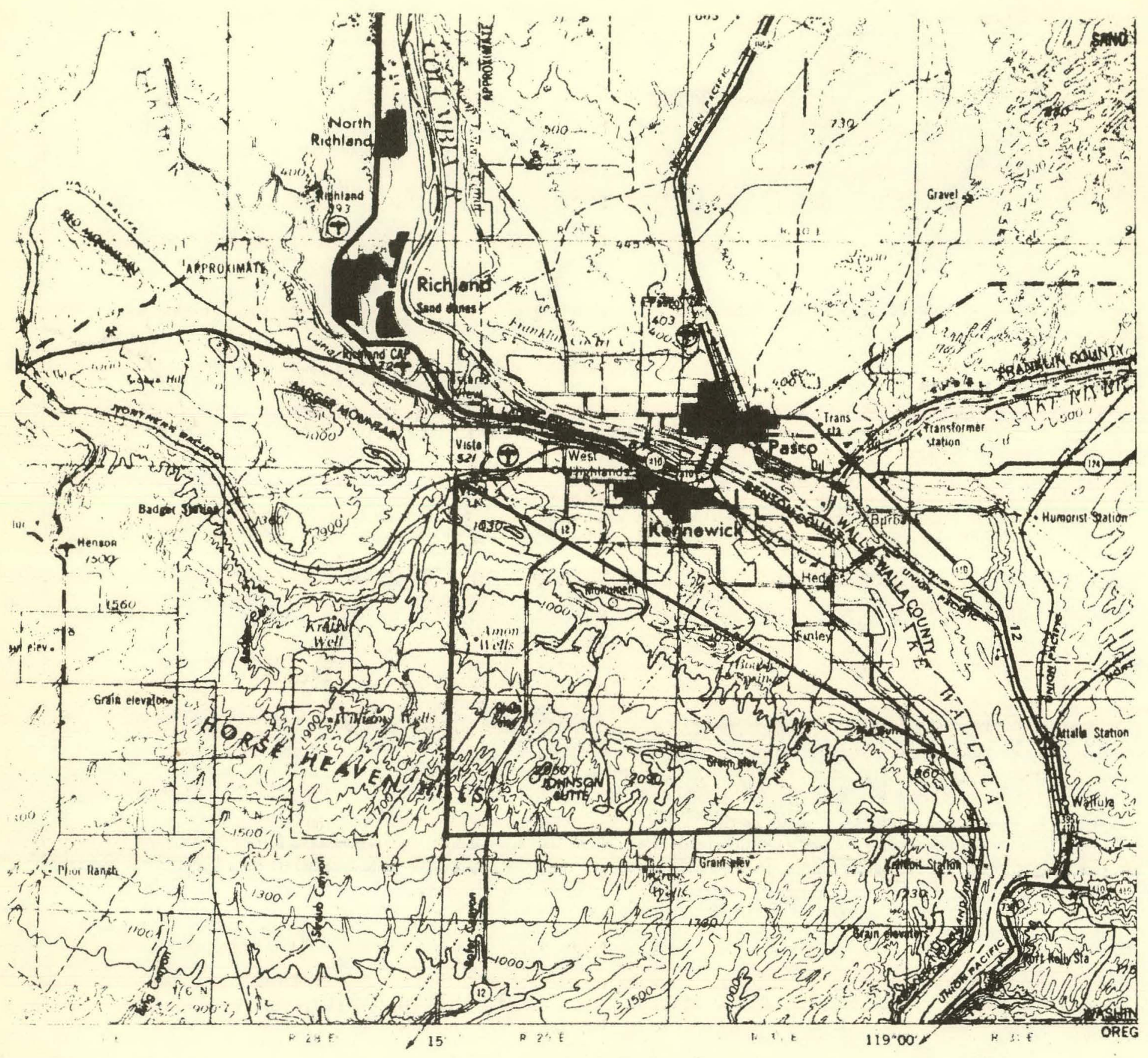

FIGURE 2

LOCATION MAP OF THE NINE CANYON MAP AREA AND VICINITY

-Indicates boundary.) 


\section{METHODS OF INVESTIGATION}

Geologic mapping was done on U. S. Geological Survey 7.5-minute topographic sheets and transferred to a composite map at 1:24,000 scale. A total of 60 days was spent in the field between October 1977 and July 1978.

Individual stratigraphic units of Columbia River Basalt were identified on the basis of physical characteristics, whole rock major element chemical analysis using X-ray fluorescence analysis, semiquantitative chemical analysis for $\mathrm{CaO}, \mathrm{TiO}_{2}$, and $\mathrm{BaO}$ using an onsite energy dispersive $X$-ray unit and magnetic polarity using a Calex Mode 10 Fluxgate Magnetometer. Field notes and sample localities were recorded in controlled field notebooks and shown on Figures 3-A and 3-B.

Judgment was made if the sample should be submitted for a complete $X$-ray fluorescence major element analysis, if an energy dispersive X-ray analysis would be sufficient, or if no chemical analysis was necessary (in many instances, magnetic polarity, combined with known stratigraphic relationships at a particular locality, were sufficient). Geologic mapping, sampling, magnetic polarity measurements, and other aspects of this work were performed in accordance with Rockwell Hanford Operations standard operating procedures.

\section{PREVIOUS WORK}

Although geologic studies of the Columbia Plateau are becoming increasingly abundant, previous work in the Nine Canyon Map Area (Figures 1 and 2) has been limited. Raisz (1945) first noted the physiographic alignment of hills in the Rattlesnake Hills-Wallula Gap area and postulated the existence of a major structural lineament extending from the 0lympic Mountains in western Washington to the Wallowa Mountains in northeastern Oregon.

Laval (1956) measured several detailed sections throughout central Washington, two of which lie within the Nine Canyon Map Area (Area VIII, No. 14, Finley Quarry on the west end of The Butte; and, No. 15, Nine Canyon). He noted breccia outcrops along the Rattlesnake Hills-Wallula Gap alignment, but stated they were not traceable for more than 30 meters. He also reported a fault zone some 150 meters wide at the west 


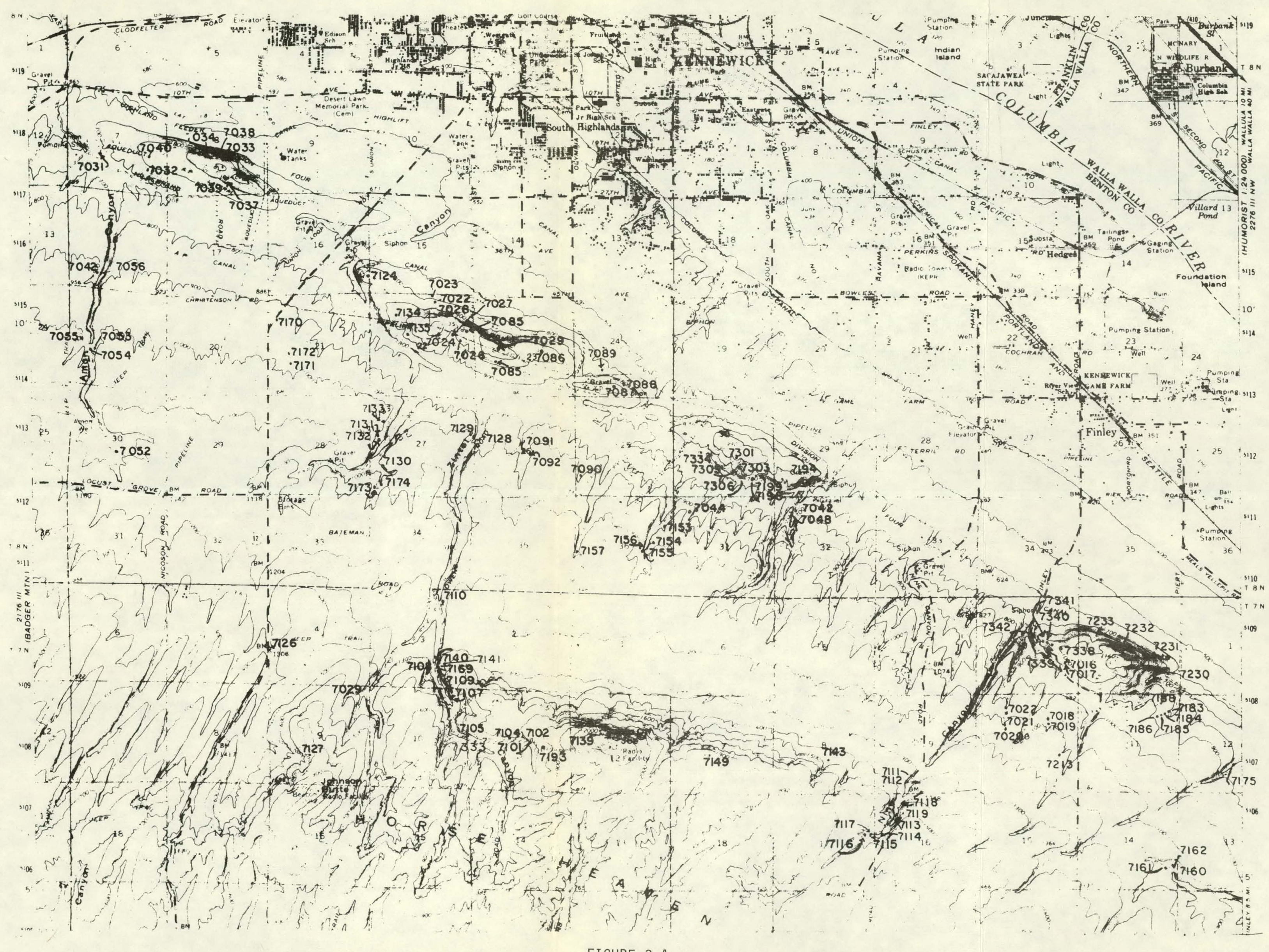




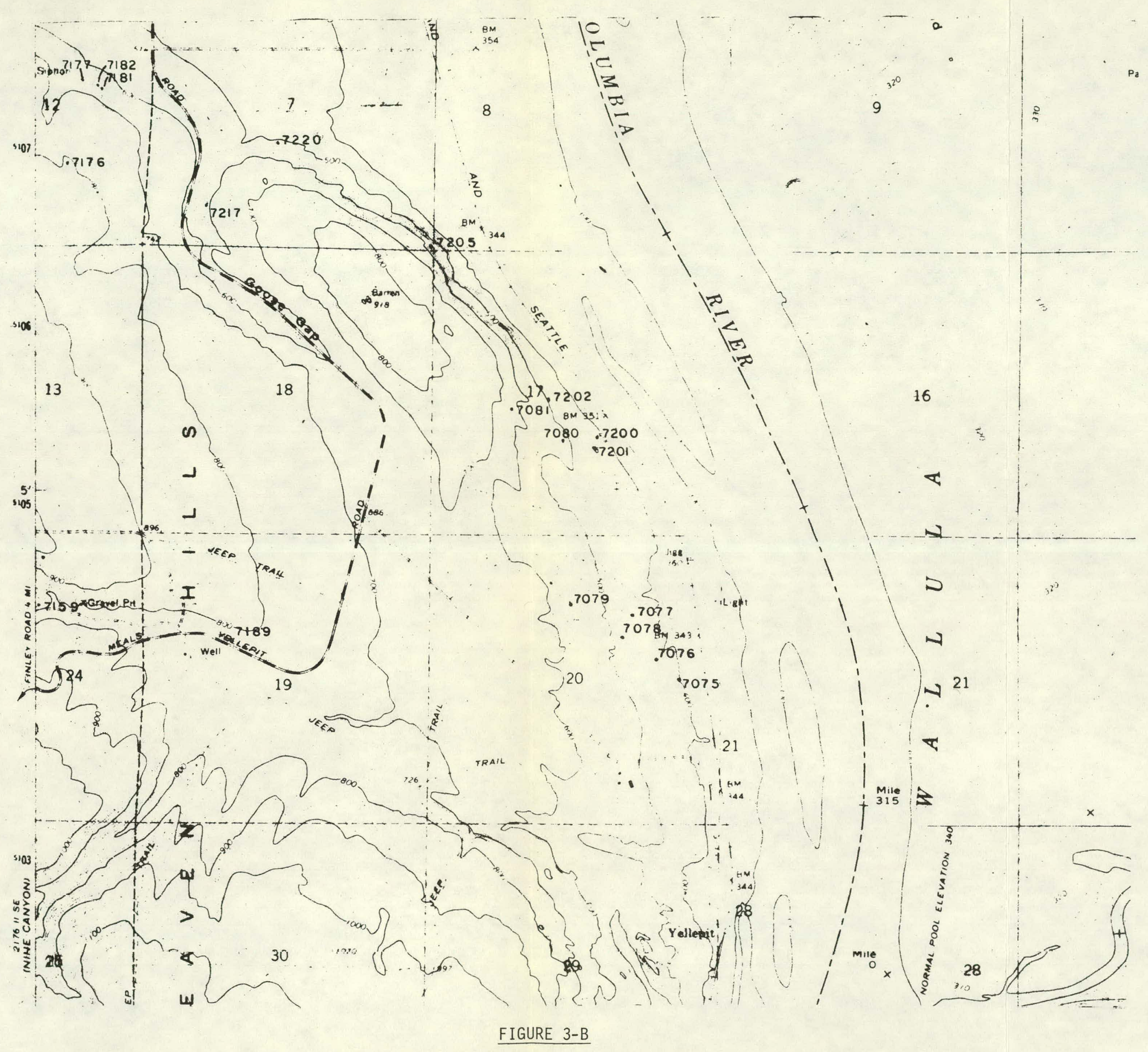

SAMPLE LOCATION MAP OF THE WALLULA 7.5-MINUTE QUADRANGLE

(- Indicates sample location; all numbers preceded by C.) 
end of The Butte. Laval, however, recognized only two basalt members: the Priest Rapids; and, the "Wenas" basalts.

Jones and Deacon (1966) studied portions of the Nine Canyon Map Area and, on the basis of a photogeologic study, inferred a zone of faulting extending from the eastern part of Rattlesnake Hills southeasterly to Wallula Gap and a fault along the base of the Horse Heaven Hills from Benton City east to the Wallula Gap area.

Schminke $(1964,1967)$ reported fused tuffs and peperites in the Nine Canyon Map Area and distinguished two Elephant Mountain flows at Ward Gap.

Waldron and Bonilla (1968) conducted a brief field study of possible recent faulting in the Hanford area and recommended that the Rattlesnake Hills-Wallula Gap Lineament be further investigated in detail in order to determine the age, extent, and mode of origin of those geologic features "suggestive of recent faulting."

Brown (1968) concluded there was insufficient evidence to justify faulting either at Wallula Gap or along the north flank of the Horse Heaven Hills.

Bingham, et al., (1970) conducted a detailed investigation of the area and concluded there was sufficient indirect evidence to demonstrate that a fault existed along the Horse Heaven Hills. They also reported linear breccia outcrops along the Rattlesnake Hills-Wallula alignment and judged the breccias were tectonic in origin rather than primary flow-related structures. Faulting was also reported along the north side of The Butte.

Gardner (1977) mapped in detail the east side of Wallula Gap. He demonstrated that the Priest Rapids and Roza members of the Wanapum Basalt are absent in Wallula Gap. Gardner also showed stratigraphic offset along the eastern Wallula Gap fault.

Jones and Fecht (1977) examined the western side of Wallula Gap at Yellepit Station, where trenching performed for At lantic Richfield Hanford Company exposed the western extension of the Wallula Gap Fault.

Washington Public Power Supply System, Inc., (1977) did mapping in the area.

REGIONAL GEOLOGIC SETTING

The Columbia Plateau is made up of a thick sequence of Miocene tholei.itic flood basalts erupted from a series of linear fissures which vented an estimated 200,000 square kilometers of basalt. The study area 
lies on the southern border of the Pasco Bas in which contains the thickest known section of Columbia River Basalt on the plateau. "The Pasco Basin is a structural and topographic low which is bounded on three sides by a series of east-west-trending anticlinal ridges: the Saddle Mountains to the north; Umtanum and Yakima ridges and Rattlesnake Hills to the west; and, the Rattlesnake Hills-Wallula alignment to the south (Figure 1).

\section{ACKNOWLEDGMENTS}

We express appreciation to the staff of the Basalt Geosciences Unit of Rockwell Hanford Operations for their stimulating discussions regarding the results of the study. In particular, we would like to thank Drs. C. W. Myers, S. P. Reidel, P. E. Long, F. E. Goff, and Messrs. K. R. Fecht and J., T. Lillie. Special thanks is given to Dr. D. A. Swanson of the U. S. Geological Survey.

\section{STRATIGRAPHY}

\section{INTRODUCTION}

The Columbia River Basalt Group is comprised of five formations: the Picture Gorge; the Imnaha; the Grande Ronde; the Wanapum; and, the Saddle Mountains basalts. Of these, only two are found within the Nine Canyon Map Area: the Wanapum; and, the Saddle Mountains basalts.

A third formation, the Ellensburg Formation which was deposited concurrently with the Wanapum and Saddle Mountains basalts, is composed of clastic and volcaniclastic sediments. Time stratigraphic problems complicate relationships between the two basalt formations and the Ellensburg Formation and, therefore, the Ellensburg Formation is not included in the Columbia River Basalt Group.

One Pliocene unit, tentatively correlated with the Ringold Formation, one Plio-Pleistocene unit, the Hanford Formation (informal name), and Holocene sediments, overlie the basalt.

The stratigraphic nomenclature used in this report is shown in Figure 4 and is consistent with Swanson, et al., (1978). 


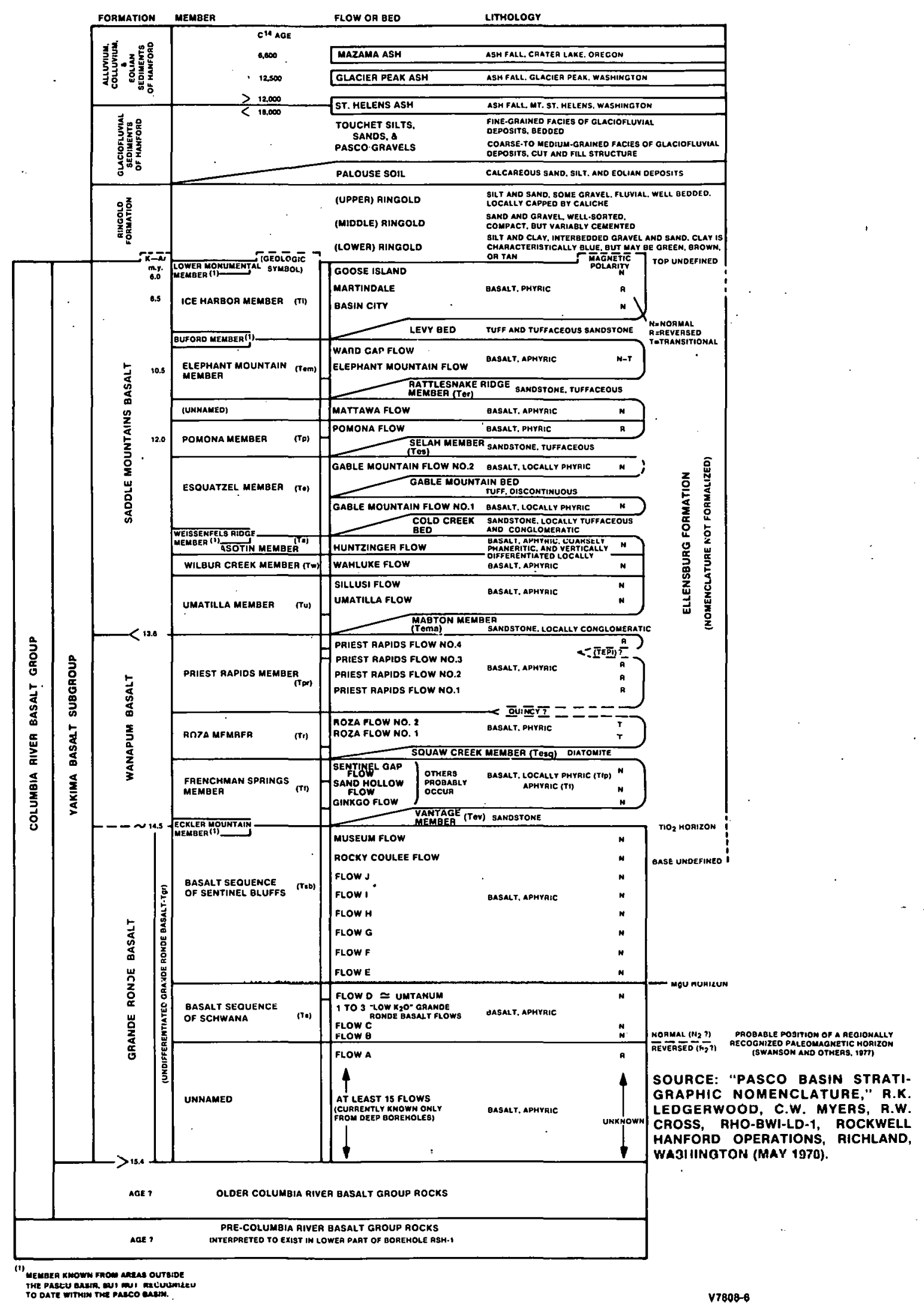

FIGURE 4 
WANAPUM BASALT

Flows of the Wanapum Basalt are exposed in only a few localities in the Nine Canyon Map Area. Recent mapping by Mr. J. N. Gardner in 1977 on the east side of Wallula Gap has shown that the Priest Rapids and Roza members of the Wanapum Basalt are absent in the immediate Wallula Gap area. Our findings are consistent with this in the eastern portion of the Nine Canyon Map Area; however, Priest Rapids flows are found approximately 16 kilometers due west along the south side of Game Farm Hill and in Zintel Canyon.

\section{Frenchman Springs Member}

One or possibly two flows of the Frenchman Springs Member are exposed at the west end of the Last Rattle on the very eastern-most edge of the Nine Canyon Map Area. Exposure is 1 imited to a small portion underlying the Umatilla Member south of the canal siphon (Section 7, Township 7 North, Range 31 East) (abbreviated Sec. 7, T7N, R31E) and a faulted block just north of the siphon. In hand specimen, the rock is greenish-gray medium-grained, and sparsely plagioclase-phyric. The Frenchman Springs Member exhibits normal natural remanent magnetism throughout. The Frenchman Springs Member has been dated by the ${ }^{40} \mathrm{~K} /{ }^{40}$ Ar method at between 14.5 million years and 13.6 million years old (Swanson, et al., 1978). Brecciated outcrops of Frenchman Springs Member are present 0.6 kilometer east. The breccias are composed of red, orange, brown, and black angular fragments of massive and vesicular basalt set in a matrix of brownish clay. Due to poor exposure of the Frenchman Springs Member, flow thickness and intraflow structures are uncertain.

\section{Priest Rapids Member}

The Priest Rapids Member is typically gray-green in color, diktytaxitic, and sparsely plagioclase-phyric. The Priest Rapids is distinct from the other Wanapum Basalt members chemically, as well as in hand specimen.

Swanson, et al., (1978) distinguished two distinct chemical types for the Priest Rapids Member: the Lolo (Wright, et ail., 1973); and, the Rosalia chemical type, with the Lolo having higher MgO and $\mathrm{CaO}$ than the Rosalia type. In the study area, these two types are seen with the Lolo type flow overlying the Rosalia type flows (Table I). The Priest Rapids 
TABLE I

X-RAY FLUORESCENCE ANALYSIS

\begin{tabular}{|c|c|c|c|c|c|c|c|c|c|c|c|c|}
\hline SAMPLE NO. & $\underline{\mathrm{SiO}}_{2}$ & ${ }^{A 1}{ }_{2} \underline{0}$ & $\underline{\mathrm{TiO}}_{2}$ & $\mathrm{Fe}_{2} \underline{O}_{3}$ & $\mathrm{Fe}_{2} \underline{O}$ & $\underline{M n O}$ & $\underline{\mathrm{CaO}}$ & $\underline{\mathrm{MgO}}$ & $\underline{K}_{2} \underline{O}$ & $\mathrm{Na}_{2} \underline{O}$ & $\underline{P}_{2} \underline{0}_{5}$ & MEMBER NAME \\
\hline C7024 & 52.53 & 15.12 & 1.66 & 2.00 & 8.22 & 0.17 & 11.25 & 5.90 & 0.48 & 2.41 & 0.24 & Pomona \\
\hline $\mathrm{C} 7037$ & 51.52 & 15.15 & 1.56 & 2.00 & 9.06 & 0.18 & 10.73 & 6.73 & 0.54 & 2.28 & 0.23 & Pomona \\
\hline C7055 & 50.87 & 13.26 & 3.41 & 2.00 & 12.93 & 0.22 & 8.65 & 4.40 & 1.38 & 2.43 & 0.44 & Elephant Mt. \\
\hline C7104 & 54.77 & 14.09 & 2.73 & 2.00 & 1.1 .15 & 0.21 & 6.57 & 1.90 & 2.79 & 2.94 & 0.84 & Umatilla \\
\hline C7113 & 53.75 & 14.18 & 3.19 & 2.00 & 10.62 & 0.21 & 7.10 & 2.97 & 2.34 & 2.93 & 0.69 & Umatilla \\
\hline C7119 & 50.33 & 13.29 & 3.40 & 2.00 & 13.23 & 0.21 & 9.49 & 4.06 & 1.02 & 2.48 & 0.49 & Elephant Mt. \\
\hline C7124 & 52.43 & 14.88 & 1.58 & 2.00 & 8.47 & 0.18 & 10.70 & 6.74 & 0.67 & 2.12 & 0.23 & Pomona \\
\hline C7128 & 52.19 & 14.73 & 1.58 & 2.00 & 8.88 & 0.18 & 10.83 & 6.77 & 0.44 & 2.16 & 0.24 & Pomona \\
\hline C7129 & 50.64 & 13.45 & 3.41 & 2.00 & 13.12 & 0.21 & 8.63 & 4.39 & 1.45 & 2.21 & 0.48 & Elephant Mt. \\
\hline C7130 & 50.45 & 13.43 & 3.39 & 2.00 & 12.77 & 0.21 & 8.87 & 5.01 & 1.16 & 2.22 & 0.49 & Elephant Mt. \\
\hline C7134 & 50.38 & 13.49 & 3.40 & 2.00 & 13.28 & 0.22 & 8.66 & 4.44 & 1.43 & 2.23 & 0.48 & Elephant Mt. \\
\hline C7141 & 50.46 & 13.82 & 3.19 & 2.00 & 11.70 & 0.21 & 9.54 & 4.52 & 1.15 & 2.74 & 0.69 & Priest Rapids \\
\hline C7303 & 49.88 & 14.01 & 3.11 & 2.00 & 11.91 & 0.23 & 9.17 & 5.67 & 1.01 & 2.38 & 0.63 & Priest Rapids \\
\hline C7305 & 50.64 & 14.06 & 3.11 & 2.00 & 12.95 & 0.22 & 8.66 & 4.08 & 1.06 & 2.66 & 0.57 & Priest Rapids \\
\hline C7306 & 49.66 & 14.08 & 3.08 & 2.00 & 12.29 & 0.23 & 9.19 & 5.35 & 1.08 & 2.41 & 0.64 & Priest Rapids \\
\hline C7333 & 49.72 & 14.32 & 3.07 & 2.00 & 12.40 & 0.23 & 9.05 & 5.15 & 0.90 & 2.51 & 0.65 & Priest Rapids \\
\hline C7334 & 50.85 & 1.3 .93 & 3.07 & 2.00 & 12.79 & 0.24 & 8.38 & 4.29 & 1.34 & 2.59 & 0.52 & Priest Rapids \\
\hline C7338 & 47.76 & 14.03 & 3.52 & 2.00 & 13.83 & 0.24 & 9.68 & 5.31 & 0.51 & 2.38 & 0.73 & Ice Harbor \\
\hline C7339 & 50.82 & 13.93 & 3.56 & 2.00 & 12.39 & 0.21 & 8.89 & 4.21 & 1.07 & 2.42 & 0.50 & Elephant Mt. \\
\hline C7340 & 51.81 & 15.30 & 1.61 & 2.00 & 8.78 & 0.18 & 10.84 & 6.59 & 0.41 & 2.25 & 0.23 & Pomona \\
\hline C7341 & 51.54 & . 15.08 & 1.68 & 2.00 & 9.00 & 0.19 & 10.71 & 6.85 & 0.48 & 2.22 & 0.25 & Pomona \\
\hline C7342 & 54.97 & 14.68 & 2.57 & 2.00 & 10.60 & 0.22 & 6.14 & 2.60 & 2.92 & 2.42 & 0.89 & Umatilla \\
\hline
\end{tabular}


flows have reversed natural remanent magnetism and have been dated by the ${ }^{40} \mathrm{~K} /{ }^{40} \mathrm{Ar}$ method at greater than 13.6 million years (Swanson, et al., 1978).

The Priest Rapids Member is exposed in two localities: along Zintel Canyon (Sec. 3, T7N, R29E), where three flows are exposed; and, on the south side of Game Farm Hill ( Sec. 30, T8N, R3OE), where two flows are exposed. In Zintel Canyon, 1 meter of baked tuffaceous silt lies between the lower and middle flows. The lower and middle flows are very similar in outcrop, both exhibiting a vesicular reddish flow top. The top two flows are extensively spheroidally weathered (Figure 5) and appear to be composed of large columns 0.9 to 1.2 meters in diameter with horizontal partings every 0.3 to 0.45 meter. The lower flow also exhibits large columns 0.9 to 1.2 meters in diameter with horizontal partings every 0.45 meter. A pillowed zone is present at the base of the upper flow exposed on Game Farm Hill. Within the Nine Canyon Map Area, the top of the Priest Rapids Member appears absent and the lower portion of the flow may be unconformably overlain by the Umatilla Member of the Saddle Mountains Basalt.

\section{SADDLE MOUNTAINS BASALT}

Within the map area, there are four Saddle Mountains Basalt members exposed: the Umatilla Member (13.6 million years); Pomona Member (12.0 million years); Elephant Mountain Member (10.5 million years); and, the Ice Harbor Member (8.5 million years) (dates from Swansun, el dl., 1978).

Umatilla Member

The Umatilla Member is the thickest and most distinctive flow in the area. In hand specimen, the rock is very black and glassy and consistently aphyric, although rare plagioclase phenocrysts to 0.7 centimeter in length have been found. Glass content is so high (up to 60 percent) as to produce an excellent conchoidal fracture when the rock is broken, and a yellow-orange pseudo-palagonite upon weathered surfaces. The unusually high barium content $(3,000 \pm$ parts per million) enables rapid distinction from other flows using the energy dispersive $X$-ray unit. The Umatilla has a strong normal natural remanent magnetism throughout. 


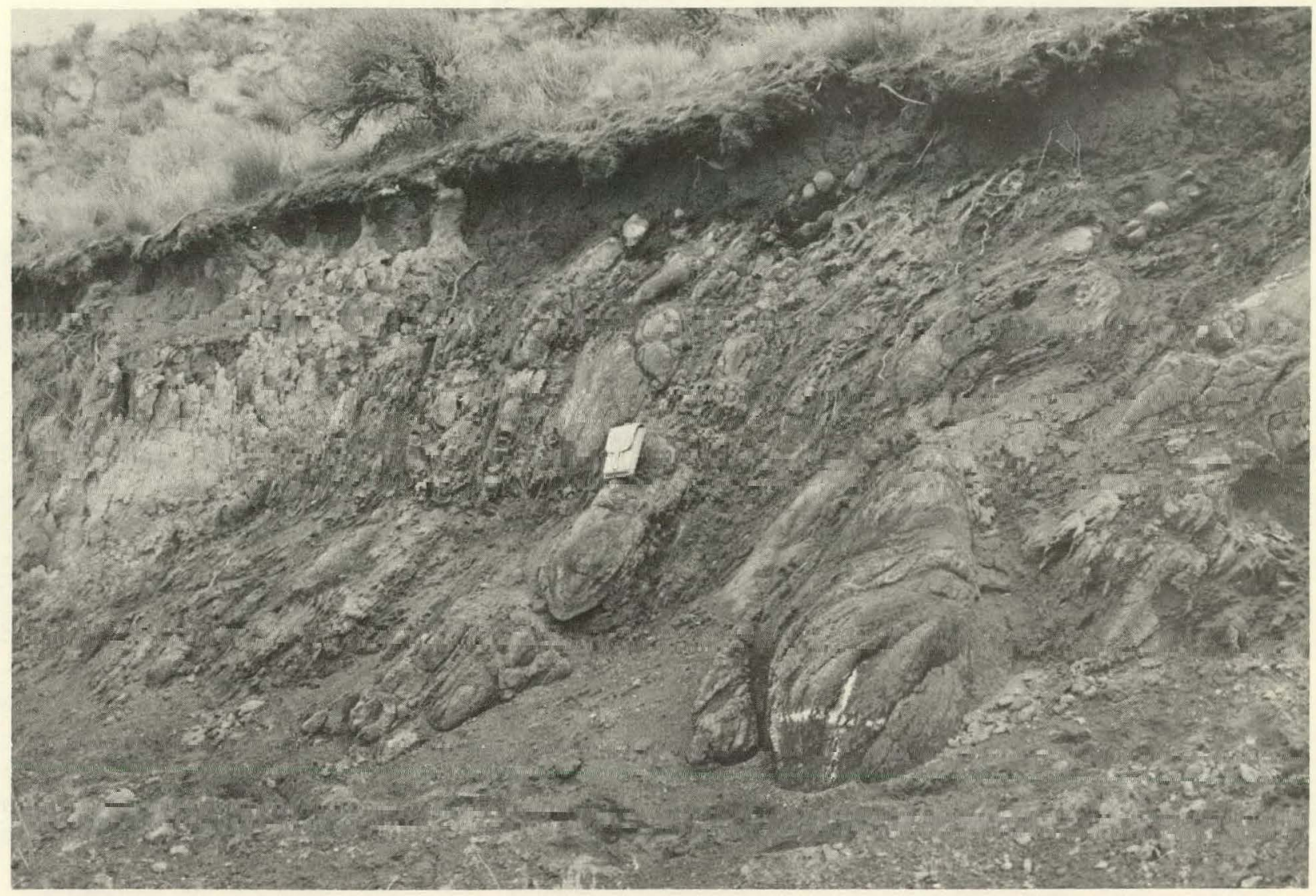

FIGURE 5

HIGHLY WEATHERED PRIEST RAPIDS MEMBER, ZINTEL CANYON 
The flow maintains a relatively consistent thickness (45 meters) throughout the map area. The entablature is typically 80 percent of the flow and forms prominent cliffs that often spall off in tall hackly blocks (Figure 6). The flow top development of the Umatilla is locally pronounced, varying in thickness from 1.3 meters to as much as 10 meters and is composed of red, orange, and lavender clinker and scoriaceous rubble. In at least two localities (Pipeline Hill, Sec. 24, and the quarry, Sec. 23, T18N, R29E), the flow top of the Umatilla was removed by erosion prior to deposition of the Pomona Member.

\section{Pomona Member}

The Pomona Member in the Nine Canyon Map Area consists of a single, moderately phyric flow, distinguishable by its stratigraphic position, reversed natural remanent magentism, and Pomona-type chemistry (Table I) (Wright, et a1., 1973). In hand specimen, the rock is gray-black or bluish-green in color, medium- to fine-grained, with moderately abundant lath-shaped plagioclase phenocrysts 0.3 to 1 centimeter in length. Sparse plagioclase glomerophenocrysts up to 2 centimeters in length occur. 01 ivine phenocrysts are present, but are commonly altered and recognizable only by their remnant crystal habit. Flow thickness varies from 3 to 27 meters; the variation is interpreted as due to erosion and thinning as the flow advanced onto the growing Horse Heaven Hills anticline. In two localities on the eastern edge of the map area, the Pomona is absent. In outcrop, the Pomona is characterized by a gray- or lavender-colored base, very vesicular where it overlies the Selah Interbed, with poorly developed columns 0.3 to 0.75 meter in diameter. The entablature has small, well-formed, wavey or fanning columns 0.3 to 0.45 meter across. Figure 7 shows a Pomona exposure on the east end of Game Farmi Hill (Sec. 29, T8N, R30E).

\section{Elephant Mountain Member}

The Elephant Mountain Member is characterized by its black color and fine-grained diktytaxitic texture. Although only very sparsely plagioclase-phyric, it is abundantly micro-porphyritic resulting in a felty textured appearance on weathered surfaces. The member has Elephant Mountain chemical type (Wright, et a1., 1973) of moderate calcium (8.7 percent) and high titanium ( 3.4 percent) (Tables I and II). 


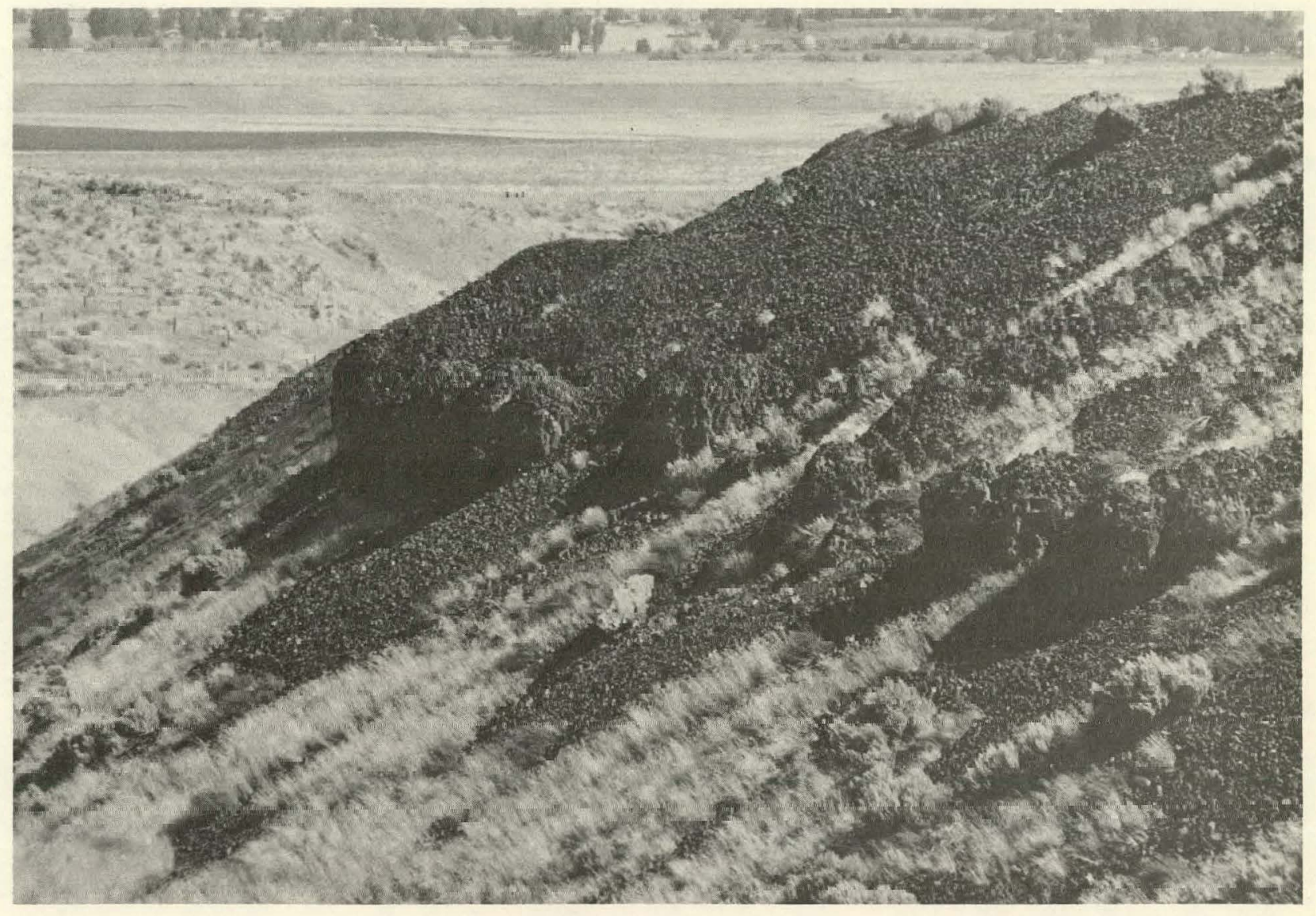

FIGURE 6

TYPICAL UMATILLA MEMBER OUTCROP, THE BUTTE 


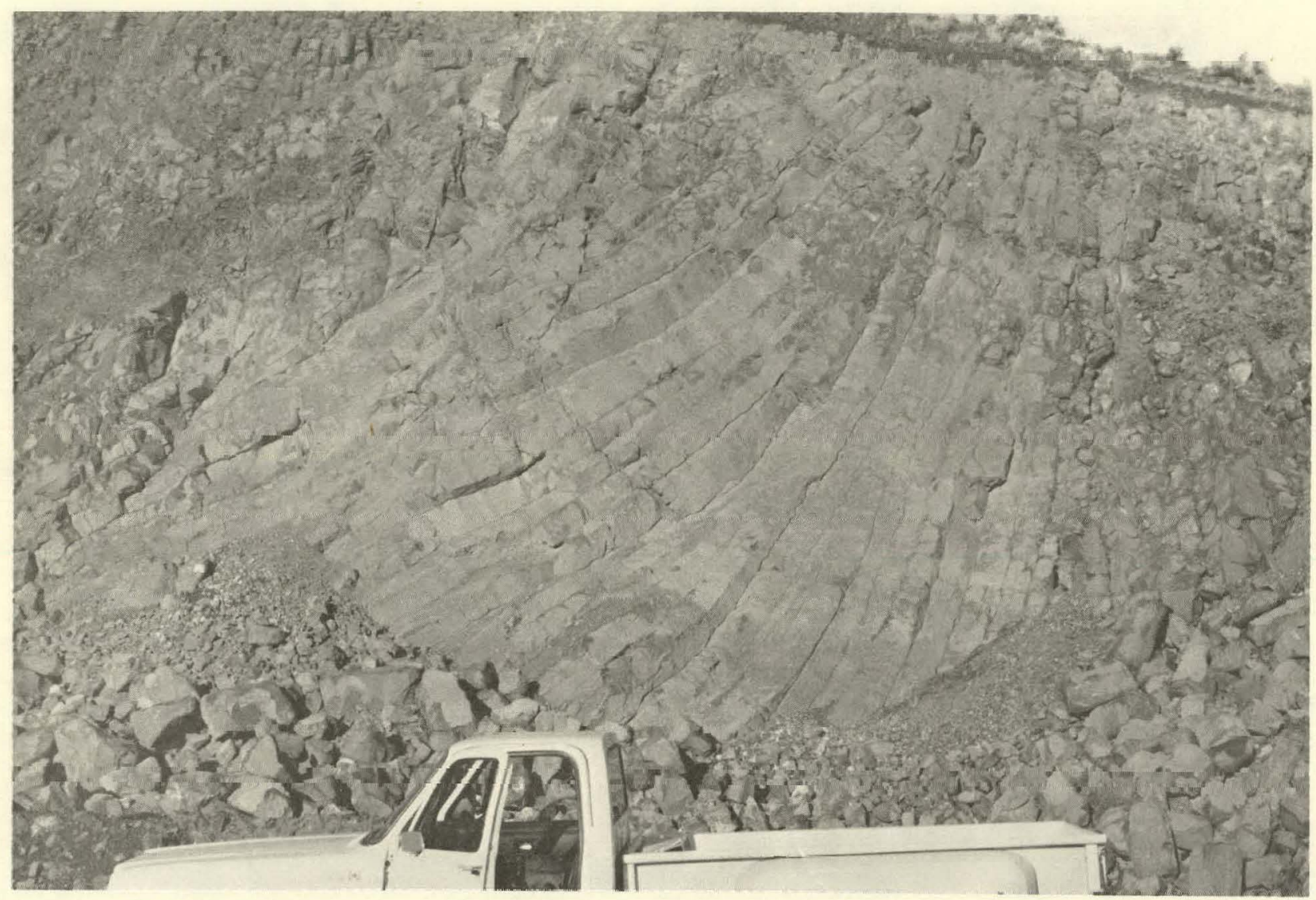

I IGURE 7

TYPICAL POMONA MEMBER OUTCROP, GAME FAPII HILL 


\section{TABLE II}

SEMI-QUANTITATIVE ENERGY DISPERSIVE X-RAY CHEMISTRY RESULTS

(Al1 values in weight percent)

\begin{tabular}{|c|c|c|c|c|c|}
\hline SAMPLE NUMBER & & $\underline{\mathrm{CaO}}$ & $\underline{\mathrm{TiO}}_{2}$ & $\underline{B a}$ & MEMBER NAME \\
\hline C7011 & & 6.7 & 2.1 & low & Elephant Mt. \\
\hline $\mathrm{C} 7012$ & & 6.3 & 2.1 & low & Elephant Mt. \\
\hline$C 7013$ & & 6.7 & 2.8 & low & Elephant Mt. \\
\hline C7014 & & 9.2 & 1.8 & low & Pomona \\
\hline$C 7015$ & & 8.1 & 2.7 & low & Ice Harbor* \\
\hline C7016 & 8 & 9.6 & 2.6 & low & Ice Harbor* \\
\hline$C 7017$ & & 7.8 & 2.4 & low & Elephant Mt. \\
\hline C7018 & & 7.6 & $2: 7$ & low & Elephant Mt. \\
\hline C7019 & & 7.8 & 2.7 & low & Elephant Mt. \\
\hline $\mathrm{C} 7020$ & & 7.5 & 2.5 & low & Elephant Mt. \\
\hline C7021 & & 8.5 & 2.3 & low & Elephant Mt. \\
\hline C7024 & & 7.2 & 1.4 & low & Pomona \\
\hline C7025 & & 7.7 & 1.4 & low & Pomona \\
\hline C7026 & & 7.2 & 1.8 & low & Pomona \\
\hline C7027 & & 6.7 & 2.6 & low & Ice Harbor* \\
\hline C7028 & & 7.2 & 2.2 & low & Elephant Mt. \\
\hline C7029 & $\cdot$ & 6.7 & 1.8 & low & Pomona \\
\hline C7030 & & 7.2 & 1.2 & Tow & Pomona \\
\hline C7031 & & 7.8 & 1.3 & low & Pomona , \\
\hline $\mathrm{C} 7032$ & & 7.0 & 2.4 & low & Elephant Mt. \\
\hline C7033 & & 7.0 & 2.4 & low & Elephant Mt. \\
\hline C7034 & & 7.6 & 3.2 & low & Elephant Mt. \\
\hline C7036 & & 8.6 & 2.4 & low & * \\
\hline C7037 & & 8.7 & 2.4 & low & * \\
\hline
\end{tabular}

* = Results are inconclusive. 
Table II (continued)

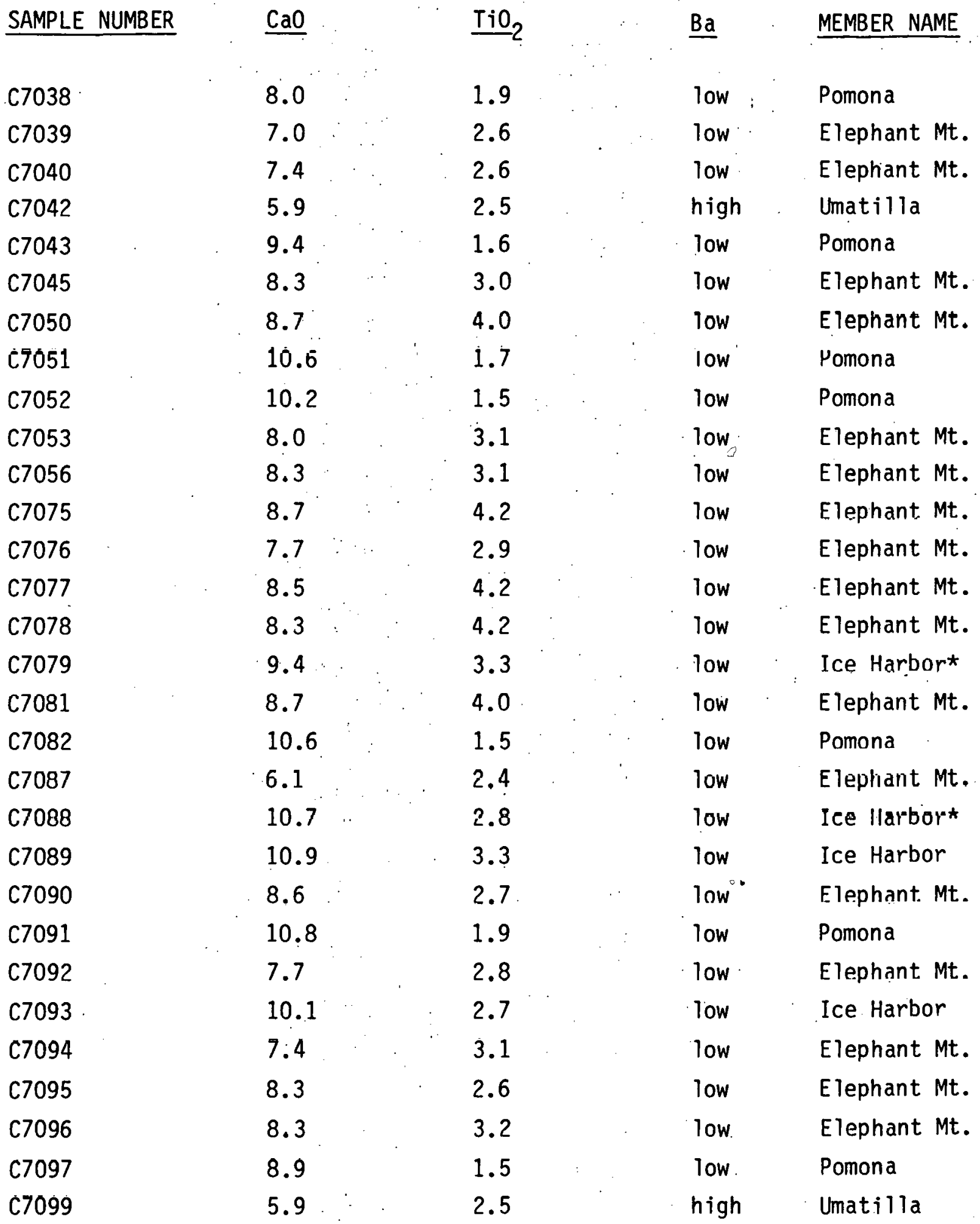

* = Results are inconclusive. 
Table II (continued)

SAMPLE NUMBER

C7100

C7101

C7102

C7103

C7104

C7105

C7106

C7107

C7108

C7109

C7110

C7111

C7112

C7113

C7114

C7115

C7116

C7118

C7119

C7120

C7121

C7122

C7123

C7124

C7125
$\underline{\mathrm{CaO}}$

7.6

8.8

$---$

-..

$---$

7.8

8.2

8.0

7.6

8.4

9.3

---

9.1

9.0

6.6

7.3

5.4

6.6

$---$

7.3

8.2

5.0

7.3

8.4

8.1 .
$\stackrel{\mathrm{TiO}}{-2}$

2.3

2.8

$--$

$--$

2.4

3.6

2.0

2.9

2.8

1.5

$---$

3.5

3.1

3.6

3.6

2.9

3.1

$-\cdot-$

2.9

1.6

2.0

2.4

1.6

1.4
$\underline{B a}$

MEMBER NAME

low *

low

high

high

high

low

low

low

low

low

low

high

high

moderate Umatilla

moderate Umatilla

moderate Umatilla

high

Umatilla

high . Umatilla

low

Pomona

low

low

high

low

low

low
Elephant Mt.

Umatilla

Elephant Mt.

Pomona

Pomona
Pomona

* = Results are inconclusive. 
Table II (continued)

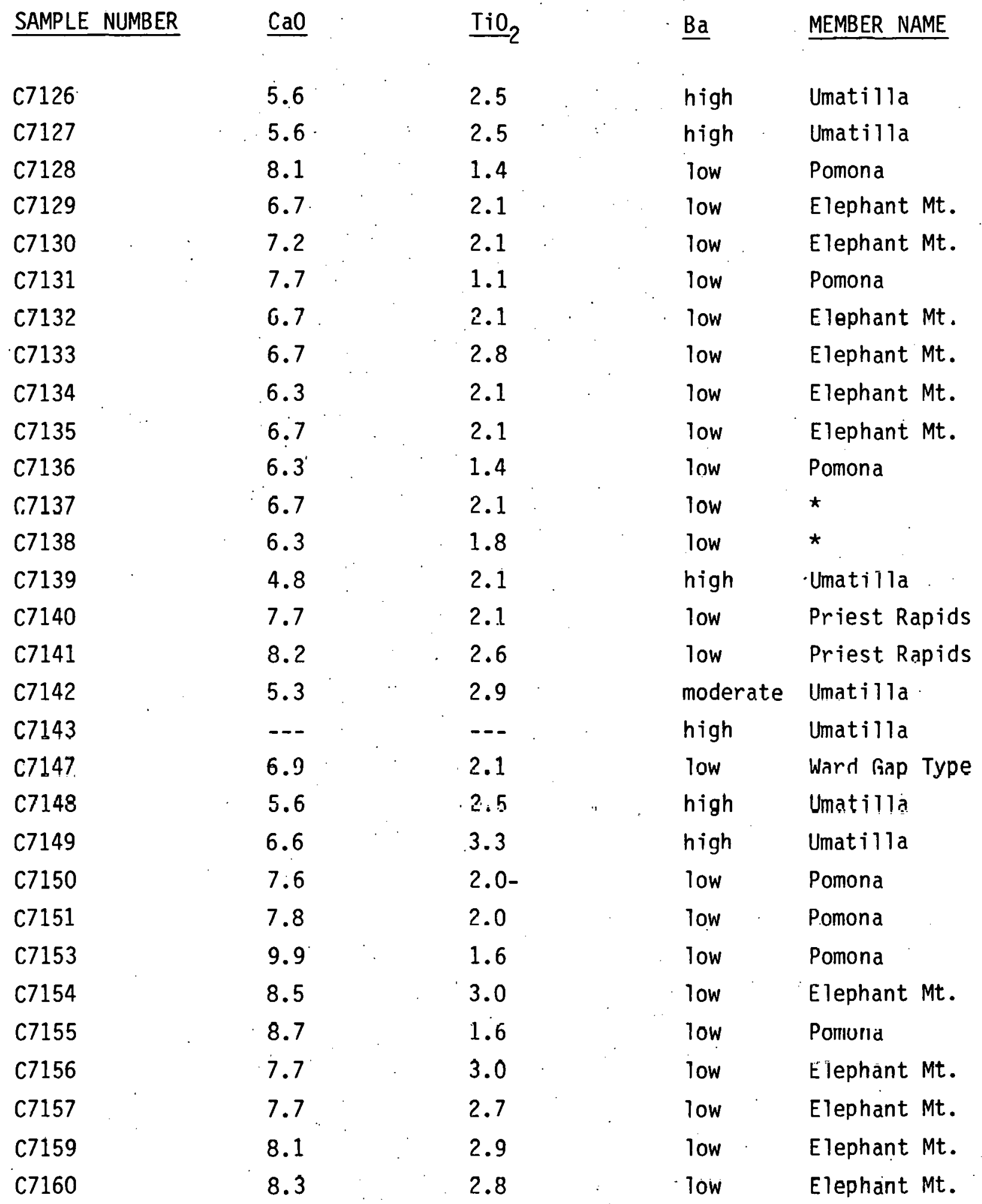

* = Results are inconclusive. 
Table II (continued)

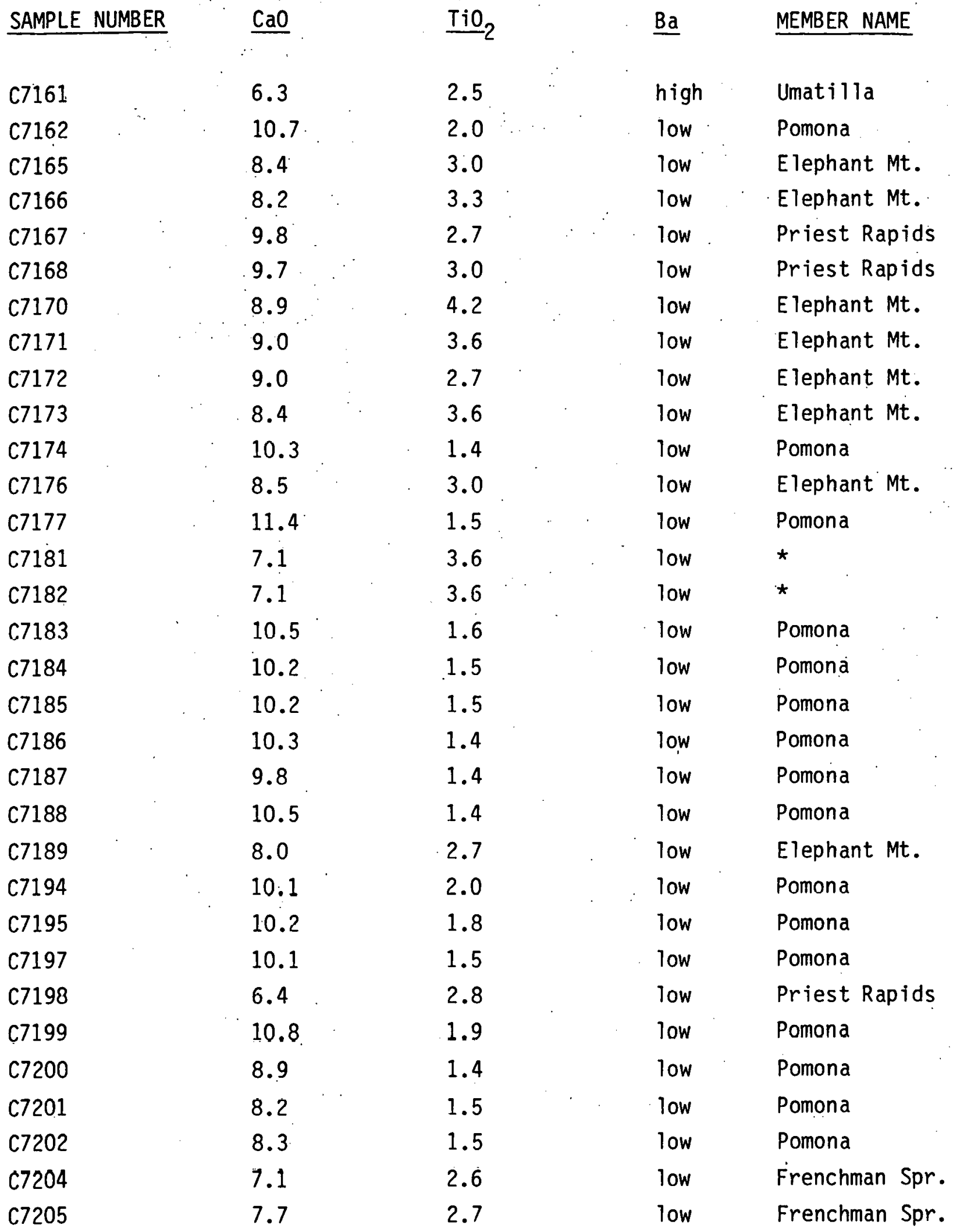

* = Results are inconclusive. 
Table II (continued)

\begin{tabular}{|c|c|c|c|c|}
\hline SAMPLE NUMBER. & $\underline{\mathrm{CaO}}$ & $\underline{\mathrm{TiO}}_{2}$ & $\underline{\mathrm{Ba}}$ & MEMBER NAME \\
\hline C7300 & 10.0 & 1.5 & low & Pomona \\
\hline C7301 & 10.5 & 1.9 & low & Pomona \\
\hline C7302 & 10.3 & 1.8 & . $10 \mathrm{w}$ & Pomona \\
\hline C7303 & 8.4 & 2.4 & low & Priest Rapids \\
\hline C7304 & 9.0 & 3.6 & low & Priest Rapids \\
\hline C7306 & 8.7 & 2.8 & low & Priest Rapids \\
\hline C7311 & 8.4 & 2.4 & low & Priest Rapids \\
\hline C7315 & 7.5 & 2.4 & low & Priest Rapids \\
\hline$C 7.316$ & 7.9 & 2.5 & low & Priest Rapids \\
\hline
\end{tabular}


Elephant Mountain flows have normal to transitional remanent magnetism making it an unreliable tool for positive identification. The Elephant Mountain Member, while widespread throughout the map area, is poorly exposed due to its tendency to form rounded slopes. It commonly weathers to a "grussic" sand and generally only the base is exposed revealing large red-brown stubby columns 1.3 to 1.5 meters across with subdued horizontal partings. In two locations (Sec. 20 and $21, T 7 N, R 30 E$ ), the base of the Elephant Mountain Member is pillowed. On the eastern edge of the map area, along the Columbia River, there appears to be two Elephant Mountain flows separated by a vesicular zone containing lenses of cherty clay. This flow has anomalous magnetics, but Elephant Mountain-like chemistry, and is tentatively correlated with the Ward Gap flow of Schminke (1967).

\section{Ice Harbor Member}

The Ice Harbor Member in the area consists of one abundantly plagioclase-phyric flow with sparse glomeroporphyritic clots of plagioclase and pyroxene to 2 centimeters or more in length. High calcium and high titanium distinguish it chemically (Table I). Reversed natural remanent magnetism indicates it is the Martindale Flow of the Ice Harbor Member. Generally, only the basal portion of the flow is exposed exhibiting large reddish stubby columns 1.5 to 2.4 meters across. In hand specimen, the rock is brownish-gray and medium grained. The Ice Harbor Member is present along the northern portion of the map area, along all of the ridges composing the Rattlesnake Hills-Wallula Gap Lineament, except Pipeline Hill, and along the Columbia River south of The Last Rattle.

\section{ELLENSBURG FORMATION}

The Ellensburg Formation in the Nine Canyon Map Area consists of the Priest Rapids, Selah, Rattlesnake Ridge, and Levy interheds. These interbeds are composed of tephra and fine-grained clastic sediments. A11 of the interbeds are discontinuous and appear to represent low areas where the sediments were protected from erosion.

\section{Priest Rapids Interbed (Informal Name)}

The Priest Rapids Interbed (Figure 8) lies between the lower and the middle flows of the Priest Rapids Member in Zintel Canyon. The light 


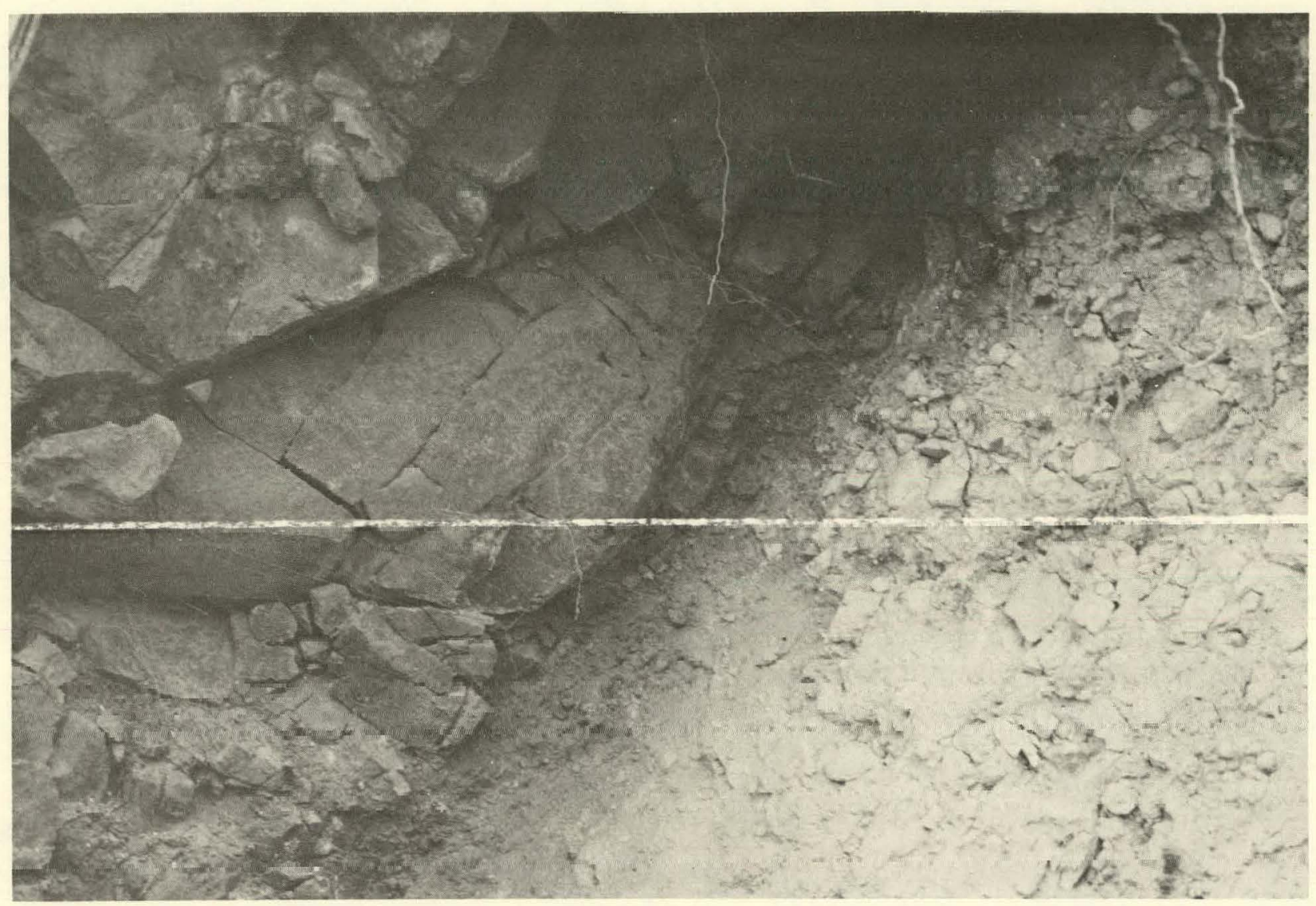

FIGURE 8

SECOND PRIEST RAPIDS FLOW OVERLYING THE PRIEST RAPIDS INTERBED 
gray sediment is composed of tephra and fine-grained silts. The top 5 centimeters of the 1-meter-thick interbed is baked to a lavender color by the overlying flow.

Selah Interbed

The Selah Interbed underlies the Pomona Member of the Saddle Mountains Basalt. This white vitric tuff varies in thickness from a few centimeters to 1.5 meters. In several localities (Sec. 5 and $6, T 7 \mathrm{~N}$, R29E and Sec. 16, T7N, R29E), well-preserved ripple marks attest to the water-laid depositional character of this clean, well-sorted ash. The top-most portion of the Selah ( 0.5 to 2.5 centimeters) has been fused to a black perlitic glass by the overlying Pomona and serves as an excellent marker where present. Occasionally, only pebble-sized fragments of the black glass mark the Pomona-Umatilla contact. An excellent peperite is exposed on the southeast end of The Last Rattle, presumably resulting from the Pomona Flow plowing into a thick pi.le of wet, unconsolidated sediments.

\section{Rattlesnake Ridge Interbed}

The Rattlesnake Ridge Interbed lies between the Pomona Member and the Elephant Mountain Member. This buff, yellow, and gray tuffaceous silt is exposed at three localities in the map area (Sec. 20, T7N, R31E, and Sec. 30, T8N, R29E) and varies in thickness from 1 to 5 meters. In the thick exposure along the Columbia River, dehydration of the top-most gray clayey portion has produced curious pseudo-columns 1 centimeter across.

\section{Levy Interbed}

The Levy Interbed underlying the Ice Harbor Member (Martindale Flow) has been found in only one locality, the eastern section bordering on the Columbia River. There, the cream-colored silty clay is approximately 3 meters thick.

\section{PLIOCENE SEDIMENTS}

The pliocene unit consists of coalesced fanglomerates exposed only along the southern flank of the anticlines composing the Rattlesnake Hills-Wallula. Gap Lineament. It is composed of angular to subangular basalt clasts, moderately well-indurated, and cemented by thick, 
well-developed calcium carbonate, rendering it fairly resistant to erosion. Absolute thickness of this unit. is unknown; however, in places, it blankets slopes lower than 300 meters in elevation, and, in one locality (Sec. 32, T8N, R3OE), it is directly overlain by Hanford Formation sediments. Stratigraphic position (although equivocal) and degree of lithification suggest this unit is more properly correlative with the Ringold Formation than with the Hanford Formation; although, due to limited exposures, we have mapped it as Hanford Formation.

\section{PLIO-PLEISTOCENE SEDIMENTS}

\section{The Hanford Formation: (Informal Name)}

The Hanford Formation consists of Touchet and Touchet-like sediments and glaciofluvial sediments. The Hanford Formation is generally found at elevations less than 320 meters and was arbitrarily mapped up to that elevation.

The Touchet sediments consist of fine-grained, rhythmically bedded sands and silts, presumably lacustrine and fluviatile deposits, left by glacial melt water floods impounded by the Horse Heaven Hills. Pebblesized non-basalt clasts of slate, quartzite, chert, granitics, and gneisses are common. Unspecified glaciofluvial sediments refer to glacial erratics--large (as much as 1.8 to 2.4 meters) granitic and gneissic boulders--apparently transported to their present locations by catastrophic flood waters or rafted in on icebergs.

\section{STRUCTURE}

\section{GENERAL}

Structural trends in the Nine Canyon Map Area are dominated by the east-west-trending Horse Heaven Hills anticlinc and the northwestsoutheast Rattlesnake Hills-Wallula Gap Lineament. The Horse Heaven Hills anticline is a broad arch with subdued synclines and anticlines superimposed on it. Jump-Off-Joe is one of these anticlines and forms part of the northern flank of the anticline. The Rattlesnake HillsWallula Gap Lineament is the southern extension of the Rattlesnake Hills anticline and is expressed as a series of low, linear hills. The structure also marks the location of the controversial 0lympic-Wallowa 
Lineament, thought by some (Raisz, 1945; Bingham, et al, 1970) to be a broad zone of deformation related to regional tectonics. Some of the anticlinal structures have been modified by faulting and all by recent erosional processes.

\section{JUMP-OFF-JOE ANTICLINE}

Jump-Off-Joe is a doubly plunging asymmetrical anticline that extends for approximately $9.6 \mathrm{kilometers}$ along the north side of the Horse Heaven Hills. The anticline is steeply dipping to the north; the gentle southern flank merges with the broad crest of the Horse Heaven Hills. The steepness of the fold along the north flank is shown along Owens Road in Zintel Canyon (cross section G-G') where steeply dipping (50 degrees northwest), heavily weathered Priest Rapids Member flows flatten out to the south into a gentle north dip. These change to a south dip farther to the south. They flatten to the north into the gently northerly dipping Pomona Member.

The east-west plunge of the anticline is seen by following the top of the Umatilla Member down slope to the east and to the west.

It has been reported in previous work (Jones and Deacon, 1966, Plates 2 and 3; Bingham, et al., 1970; Washington Public Power Supply System, Inc., 1977) that a fault exists along the north side of Jump-Off-Joe anticline. A magnetic profile done in Zintel Canyon by J. T. Lillie (1978), see Figure 9, is consistent with the interpretation of a heavily weathered basalt zone and steeply dipping interbed to the south (Figures 10, 11, and 12). Our findings show no conclusive evidence for the fault; however, additional near-surface geophysical studies are imperative for resolution of this question.

At the western end of the map area, along Washington State Highway 14 (Sec. 4, T7N, R29E), a small normal fault is exposed in the Umatilla with only a slight offset (less than 6 meters). This fault is along the projection of the fault discussed above.

\section{WALLULA GAP FAULT}

The Wallula Gap Fault (Yellepit Station Canyon, eastern border of the map area) trends north 65 degrees west and juxtaposes Frenchman Springs Basalt with Umatilla Basalt with a minimum offset of 50 meters. Several workers have speculated that this structure continues along the northern 


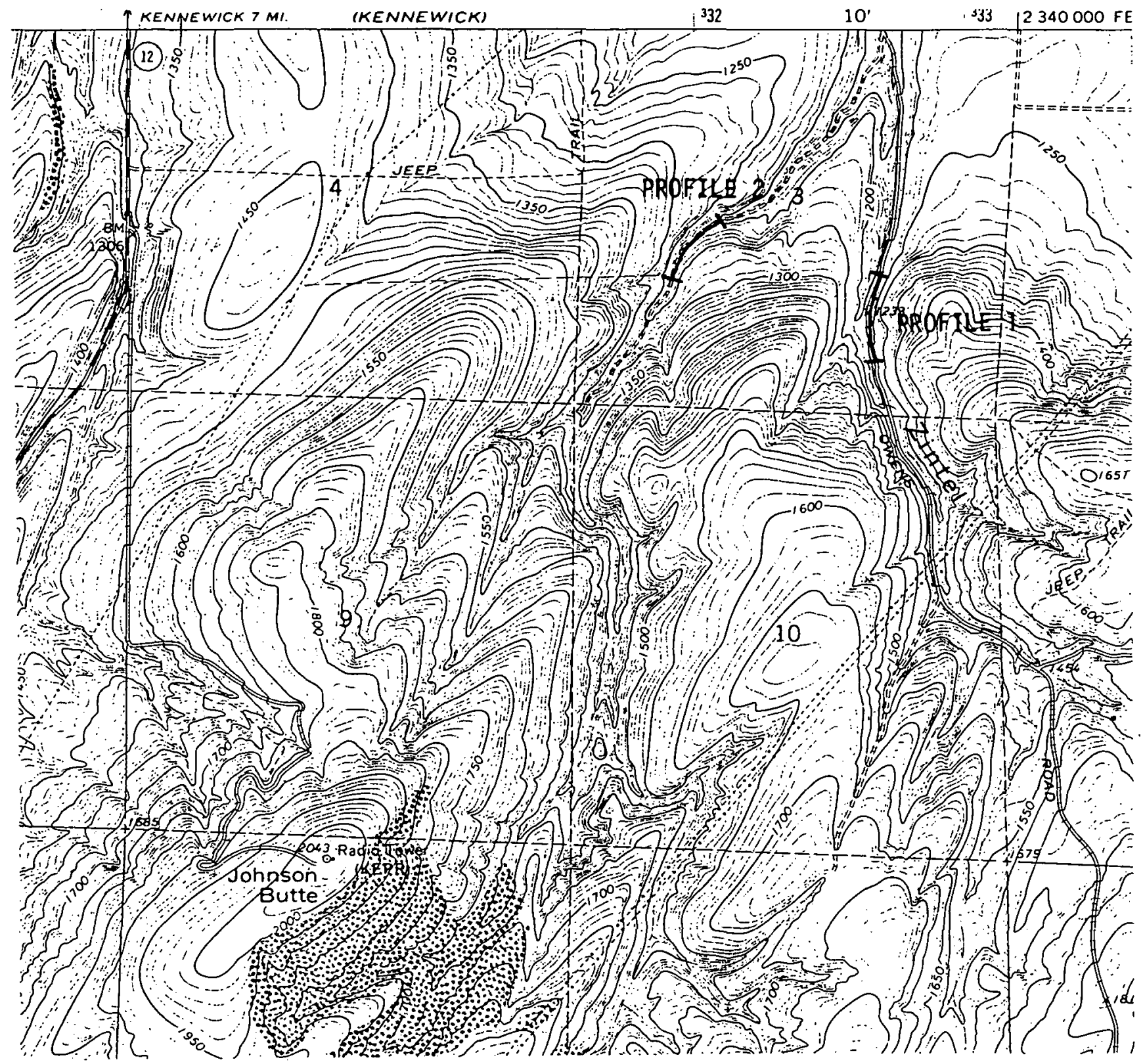

FIGIIRE 9

LOCATION MAP OF MAGNETIC PROFILES IN ZINTEL CANYON

(After J. T. Lillie, 1978.) 


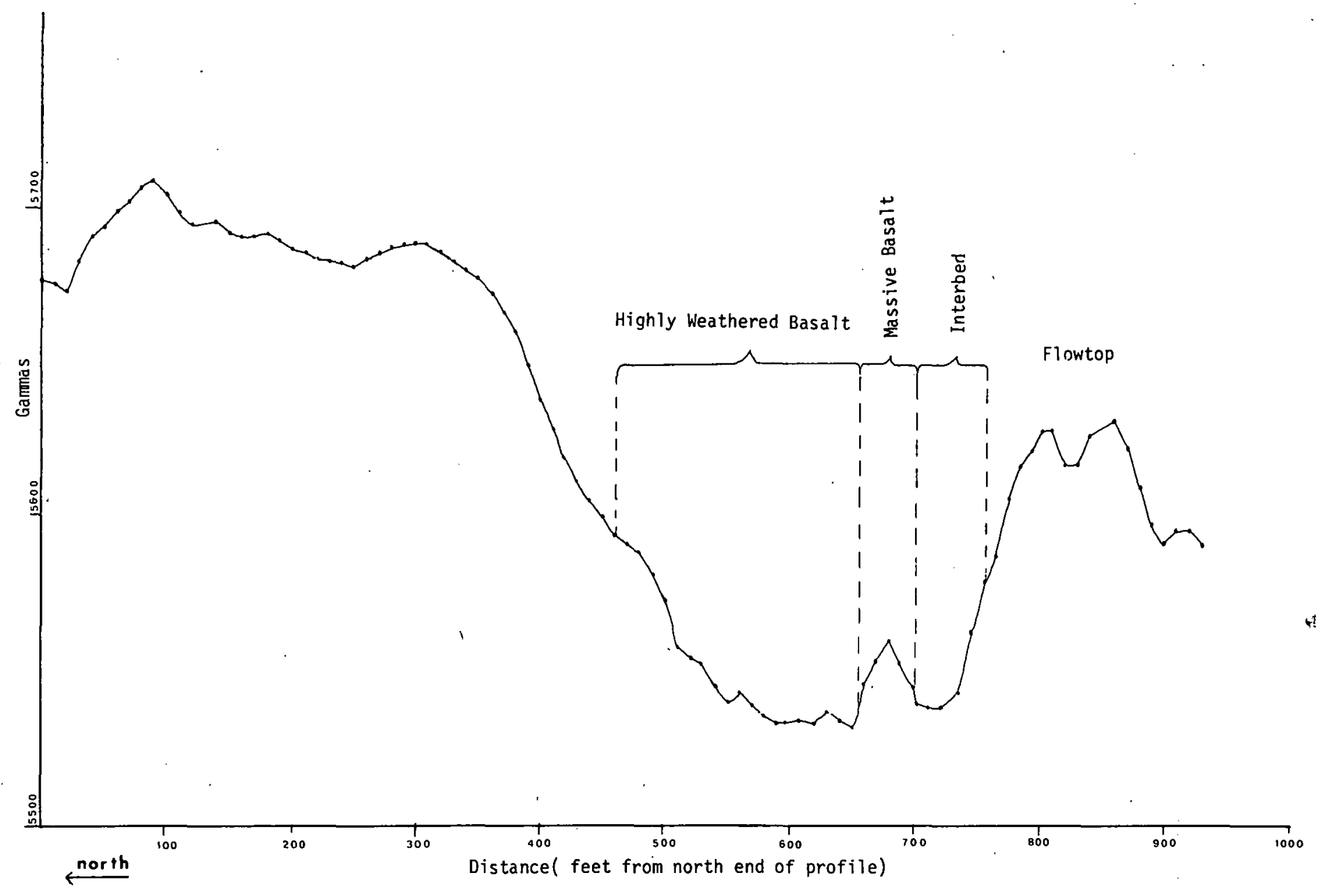

FIGURE 10

TOTAL FIELD OF PROFILE 1 VERSUS KNOWN GEOLOGY

(After J. T. Lillie, 1978.) 


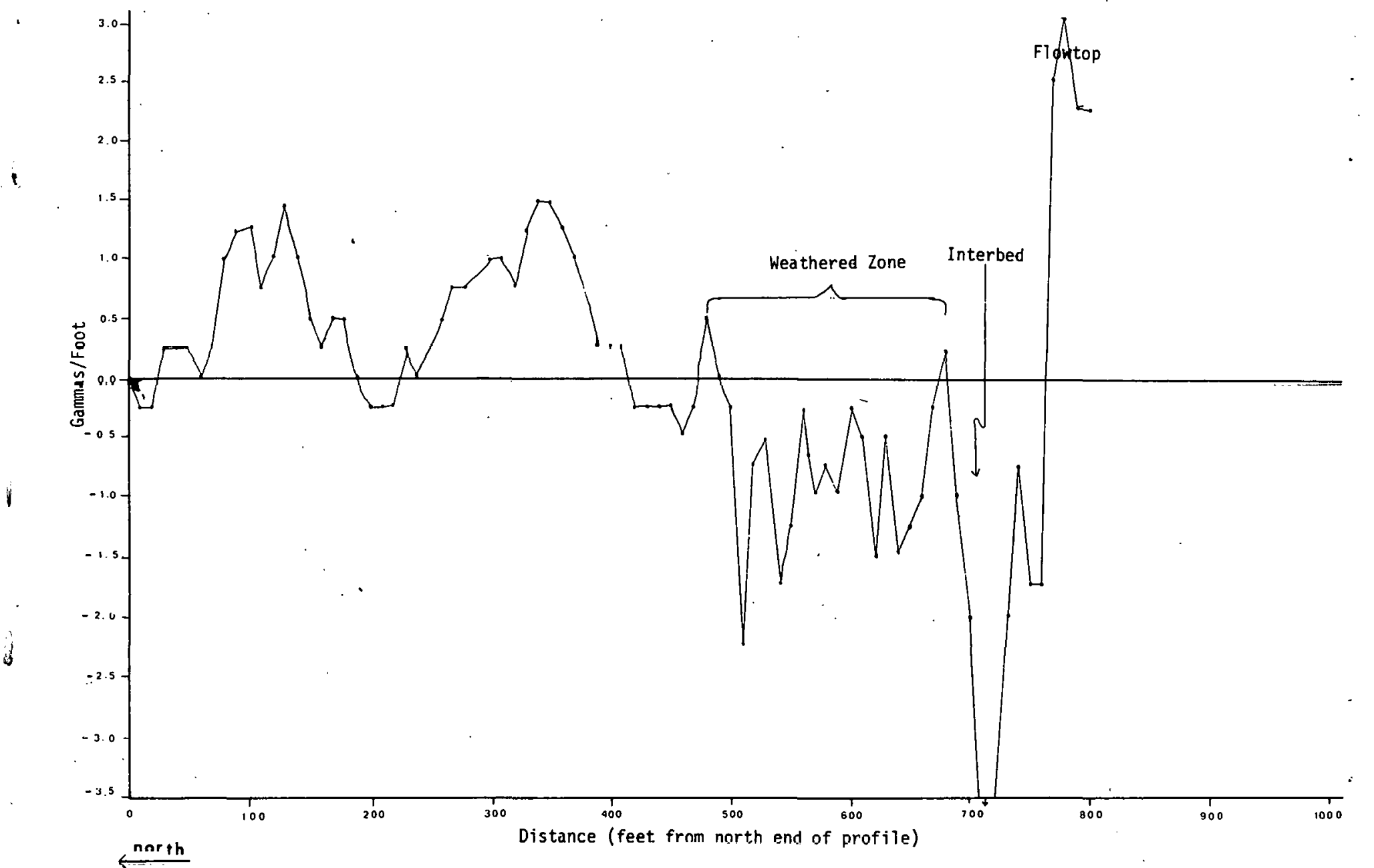

FIGURE 11

VERTICAL GRADIENT OF PROFILE I VERSUS KNOWN GEOLOGY

(After J. T. Lillie, 1978.) 


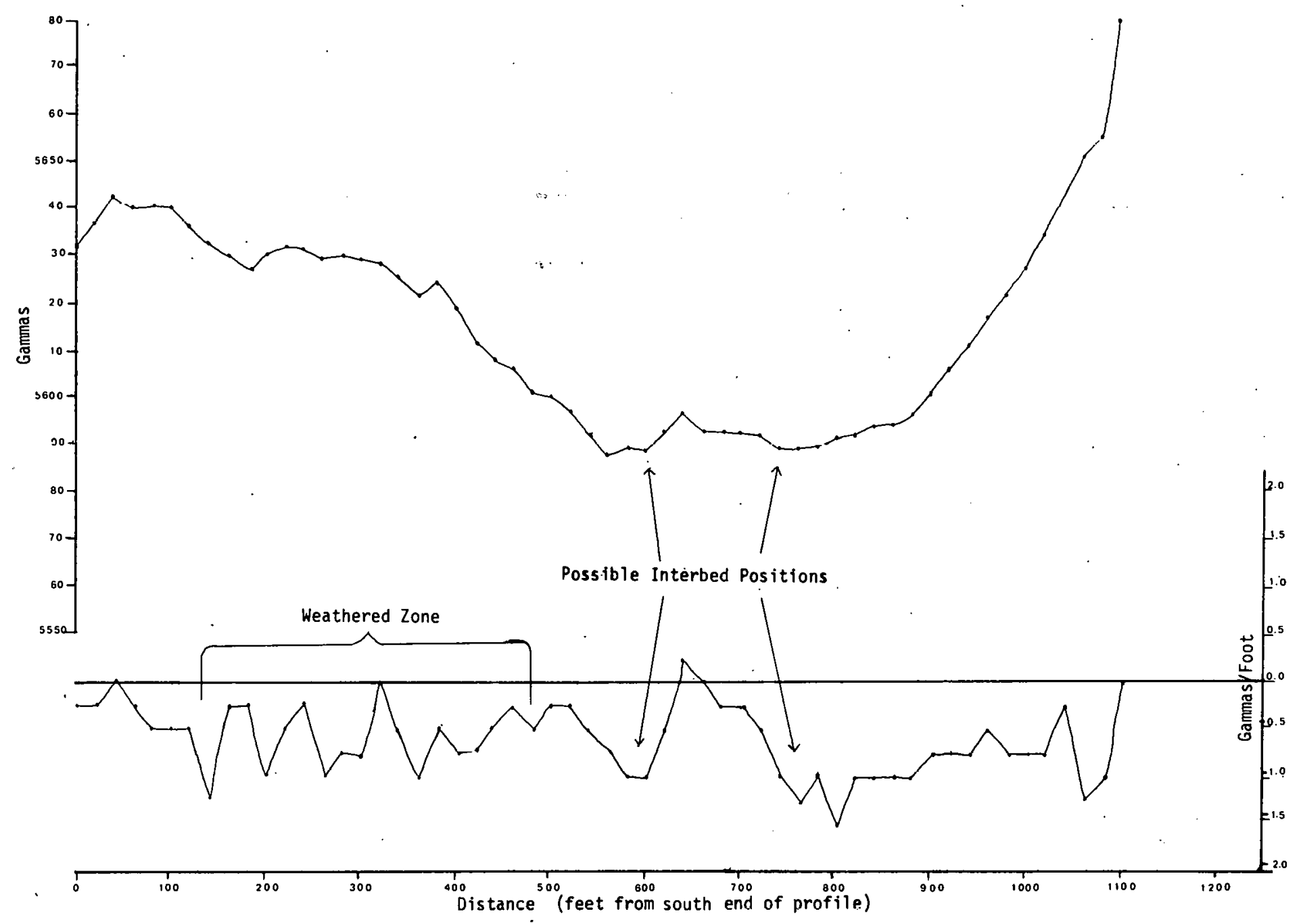

\section{FIGURE 12}

PROFILE ? IN 7 INTEL. C.ANYON

TOTAL MAGNETIC FIELD AND VERTICAL GRADIENT

(Top is total field; bottom is vertical gradient. After J. T. Lillie, 1978.) 
flank of Jump-0ff-Joe. We find no evidence for continuity farther than about 1.3 kilometers west of the Columbia River, where offset apparently dies out. However, the Wallula Gap area is being studied extensively by Mr. J. N. Gardner (University of California at Davis), Mr. K. R. Fecht. and Ms. M. G. Jones (Rockwell Hanford Operations) and, therefore, is not discussed in this report.

\section{RATTLESNAKE HILLS-WALLULA GAP LINEAMENT}

The Rattlesnake Hills-Wallula Gap Lineament (Figure 13-A and 13-B) in the Nine Canyon Map Area extends $30 \mathrm{kilometers} \mathrm{southeast} \mathrm{from} \mathrm{the} \mathrm{mouth}$ of Badger Coulee to Wallula Gap. For ease of reference, the hills are referred to informally as (east to west) The Last Rattle, The Butte, Game Farm Hill, Pipeline Hill, and Basalt Hill (Figures 13-A and 13-B). The five linear hills constitute four doubly plunging anticlines, their crestal traces are sinuously en echelon. Shallow synclines parallel the anticlines on the south, forming a trough that possibly drained the Horse Heaven Hills paleoslope.

\section{The Last Rattle}

The Last Rattle is the most tightly folded of the anticlines (Plate 6 , cross section $\left.A-A^{\prime}\right)$, trending north 60 degrees west and plunging approximately 30 degrees to the southeast under the Columbia River as it enters Walluia Gap. Two faults located on this craggy hill define a small horst. . The more southerly fault parallels the Rattlesnake Hills-Wailula liap Lineament and is probably related to The Butte fault. It juxtaposes Umatilla and Frenchman Springs members and is marked by linear breccia outcrops that trend approximately north 60 degrees west; offset is probably less than 30 meters. The second and shorter fault juxtaposes Icc Harbor and Frenchman Springs members. Threc thick interbeds, plus a wedge of Ice Harbor Basalt, suggest that the synclinal trough to the south of The Last Rattle deepens and plunges to the southeast.

\section{The Butte}

The Butte is a north-dipping monocline that has been faulted along its hinge line. The fault trends north 60 degrees west and apparently dips as low as 50 degrees to the northeast, but the pattern of the fault trace suggests steeper dips. The fault thrusts Umatilla up next to the 
LEGEND TO

FIGURES 13-A

AND 13-B AND

PLATES 1 THROUGH 6

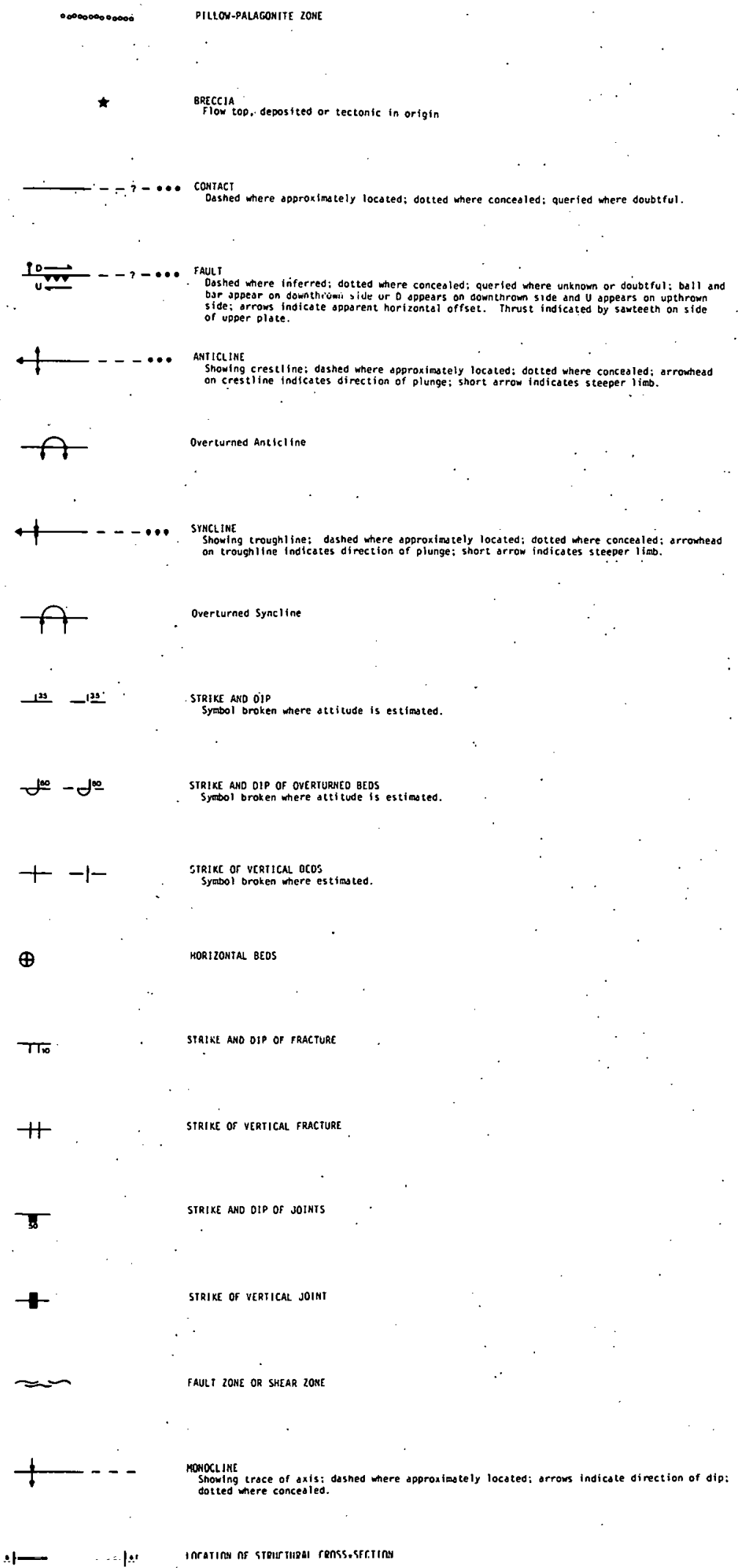


FIGURES 13-A

AND 13-B AND

PLATES 1 THROUGH 6

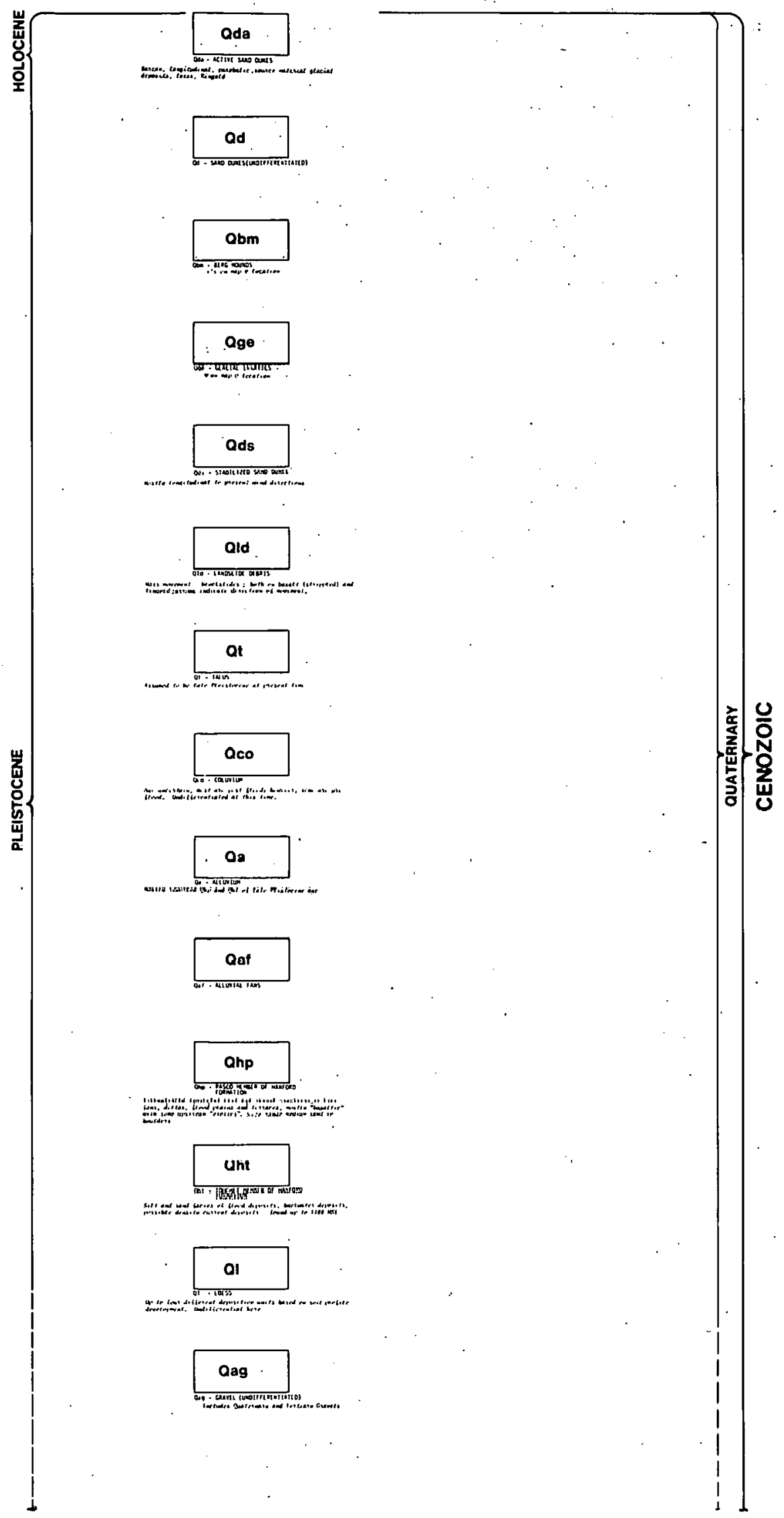




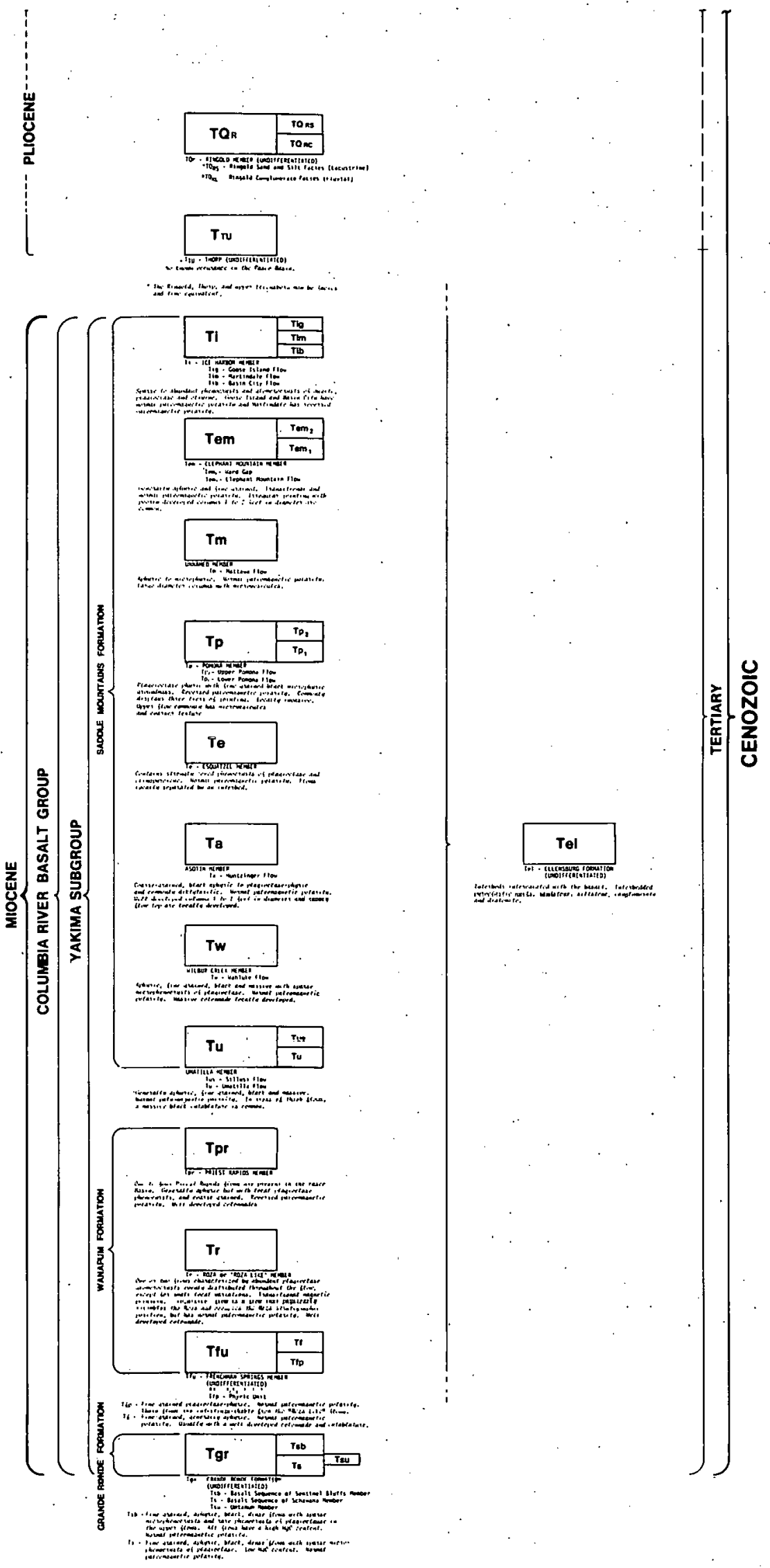




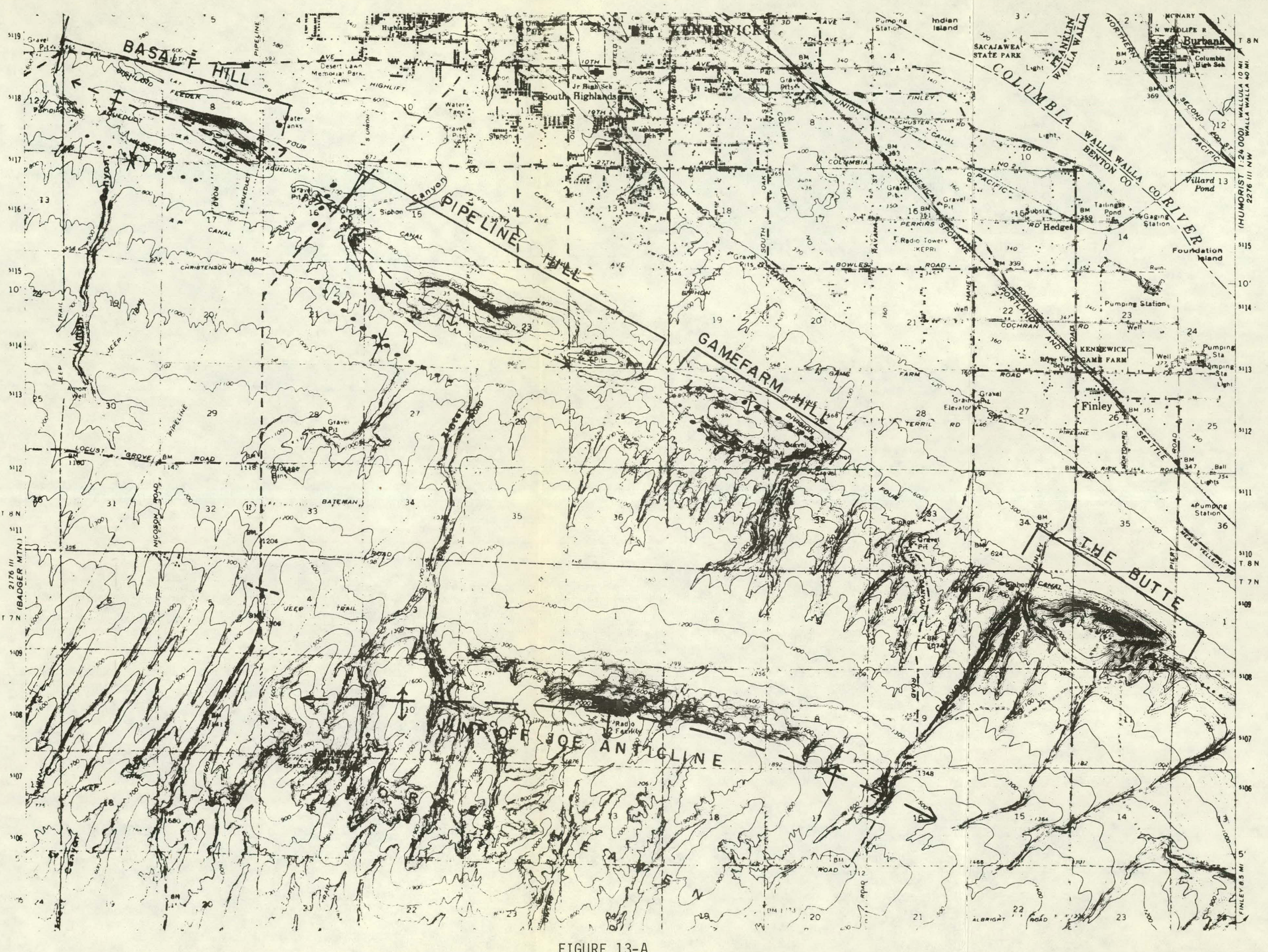




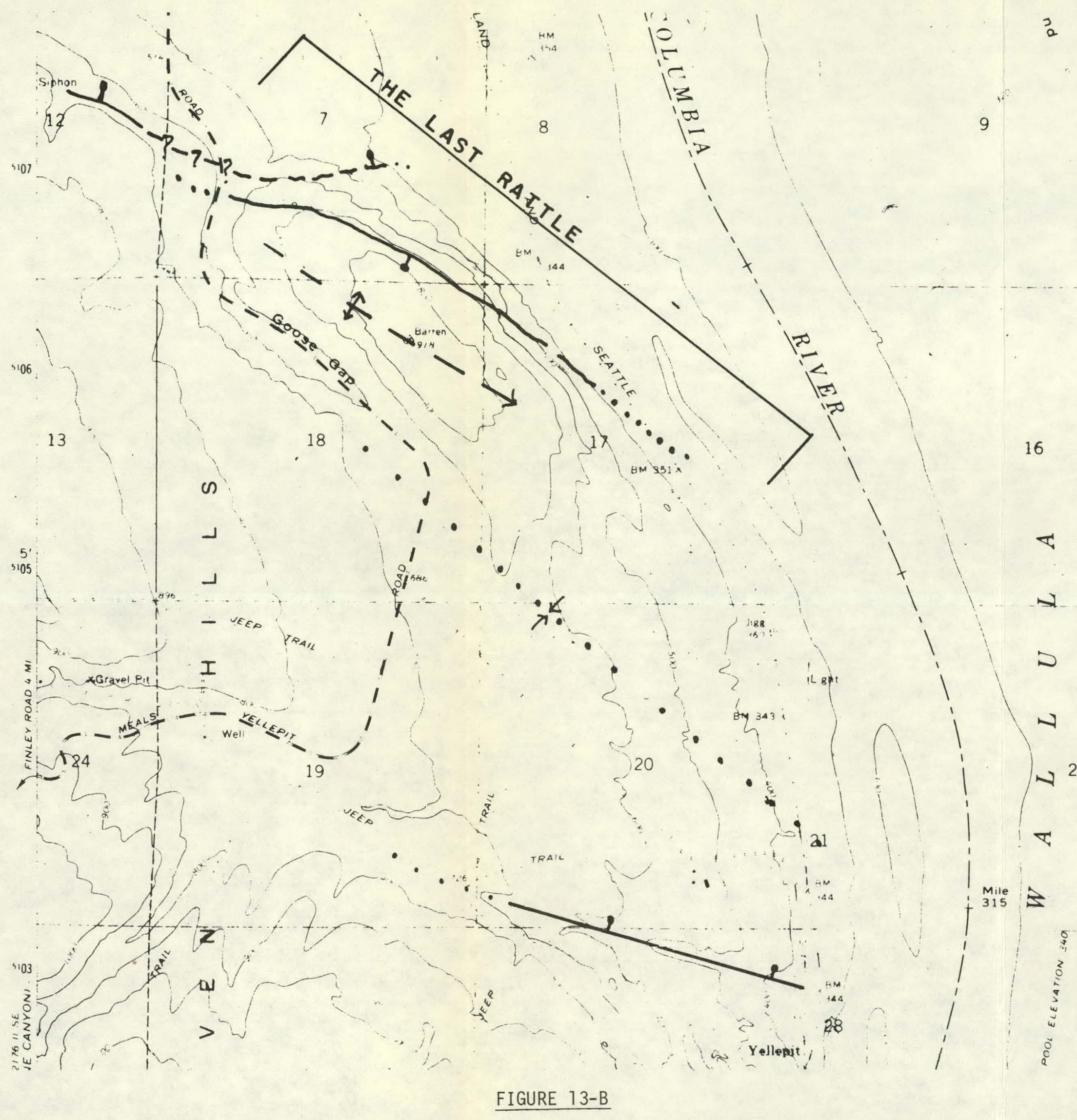

STRUCTURE AND LOCATION MAP - WALLULA 7.5-MINUTE QUADRANGLE 
flat-lying Ice Harbor Member. Steeply dipping Pomona and Elephant Mountain members are exposed on the northeast corner of The Butte; up the gully on the east end, the top of the Umatilla Flow is exposed (see cross section $\left.B_{-} B^{\prime}\right)$. However, north of the fault, the top of The Butte is composed of Umatilla Member. Offset appears to be as much as 50 meters. Much of the top of The Butte is littered with reworked Touchet- type sediments and pockets of large (2 meters $\times 2.6$ meters) sized granitic glacial erratics. Apparently, the linear gully on the north side of The Butte marks the intersection of the fault with the Pomona and the underlying Selah. Finley Quarry, on the west end of The Butte, exposes Umatilla Basalt truncated against a calcite-cemented fault breccia (Figure 14).

The Butte section contains one of the most complete sections found in the Nine Canyon Map Area with only the Wanapum Formation not exposed. The measured section obtained there is presented in the Appendix and Figure A-1.

\section{Game Farm Hill}

Game Farm Hill is a doubly plunging anticline with a small fault on the south side displacing the Umatilla Member and moving the UmatillaPomona contact on the north block up out of alignment with the projected contact plane (cross section $\left.C^{-} C^{\prime}\right)$. The fault trace is marked by fractured and sheared basalt in the Umatilla Member. Movement has been slight ( 3 to 7 meters), and the fault appears to be related to the original folding. The crest of the anticline on the north side is not exposed due to erosion and only the southerly dipping flows are exposed on the hill. The northwest-southeast plunge of the fold is shown by opposing dips on the south and north ends of the hill.

\section{Pipeline Hill}

Pipeline $\mathrm{Hill}$ is a doubly plunging anticline whose crestal trace curves to the north on its western end. No sign of faulting was found along the steep north flank. Excavation for construction of a water storage tank on the north side affords the only exposure available there. Both the Selah and flow top of the Umatilla are absent there, suggesting they were planed off prior to deposition of the Pomona. Approximately 1 kilometer to the southeast (Sec. 25, T8N, R29E) the 


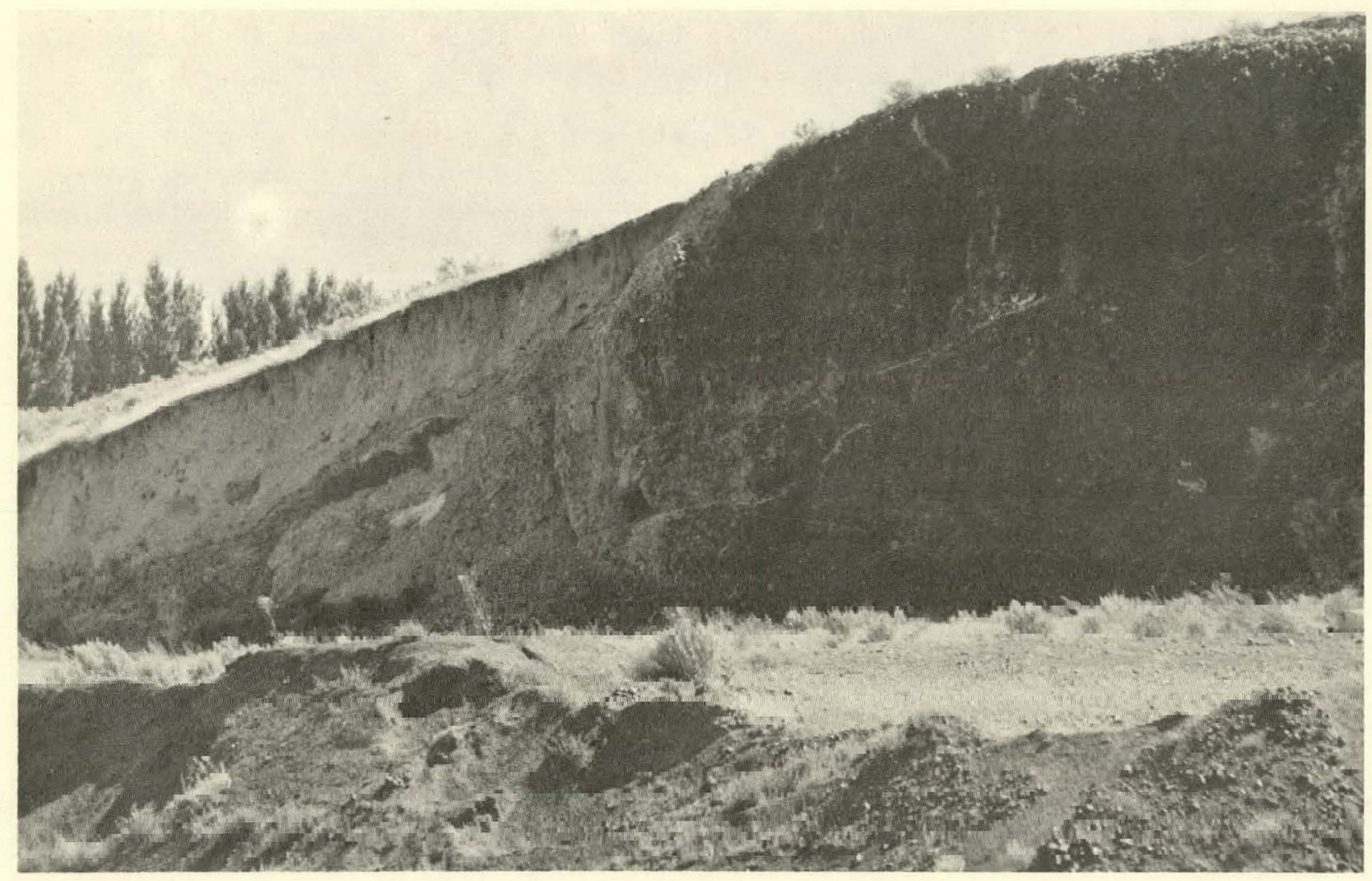

FIGURE 14

FINLEY QUARRY - THE BUTTE

CALICHE-CEMENTED FAULT BRECCIA 
southeastward plunge of this anticline is demonstrated by the Umatilla, Pomona, Elephant Mountain, and Ice Harbor members occupying a lower topographic position than they would to the northwest on the top of Pipeline Hill

Basalt $\mathrm{Hill}$

Basalt $\mathrm{Hill}$ is a doubly plunging anticline trending north 70 degrees west. A small normal fault trends north 55 degrees west across the mid-section of the ridge (see cross sections $E-E^{\prime}$ and F-F!), juxtaposing Elephant Mountain Member on the south against Umatilla Member on the north. The fault trace is marked by a shear zone (Sec. 8, T8N, R29E) and linear breccia outcrops on the west end. Offset is possibly 30 meters and apparently decreases to the west.

CONCLUSIONS

Relief existed in the immediate Wallula Gap area by at least Priest Rapids time, as indicated by the absence of any Priest Rapids flows at Wallua Gap. Whether this high was constructional or structural is unclear. The unusually thick accumulation of Frenchman Springs flows ( 9 to 10 flows, approximately 200 meters thick) present in the gap suggests close proximity to vent areas. Several thin flows of small areal extent could have built an edifice capable of excluding the Priest Rapids flows. Swanson and Wright (1976) mention a Frenchman Springs constructional high in the Devils Canyon-Ice Harbor Dam area (Figure 1). Alternatively, Dr. S. P. Reidel reports evidence in the Saddle Mountains suggesting older northwest-trending structural highs. He postulates these older highs may have extended down through the Wallula Gap area. No conclusive evidence for this hypothes is was found in the Nine Canyon Map Area.

Whatever its original nature, Priest Rapids flows lapped up onto the high, but did not cover it. Lower elevations existed to the west than at Wallula Gap, because Priest Rapids flows are found in Zintel Canyon and. on Game Farm Hill. Priest Rapids flows apparently filled many lows and reduced relief considerably as the Umatilla Member maintains a fairly consistent thickness. 
Structural uplift definitely began prior to extrusion of the Pomona and Elephant Mountain flows. Both flows lap up onto the Horse Heaven Hills; the Pomona thins from 30 meters at The Butte to only 3 meters along Nine Canyon Road 4.8 kilometers to the south, and the Elephant Mountain is not present along the anticlinal crest.

The Rattlesnake Hills-Wallula Gap Lineament is younger than the Horse Heaven Hills structure. This is indicated by the relatively constant flow thicknesses of the Pomona and Elephant Mountain members and the drainages that are deflected along the linear. Deflection increases to the west, suggesting the western portion of the lineament in the map area is older than the eastern portion. Folding along the lineament probably began post-Elephant Mountain time and continued through Ice Harbor time. It is unclear whether Ice Harbor flows once topped all of the anticlinal ridges, but, judging by its position on top of the Mound Pond Section in Wal lu la Gap (ARH-ST-137, 1976), it was probably present on all the anticlines and has been stripped off by subsequent glaciofluvial flood waters and the shifting courses of the ancestral Snake and Columbia rivers. The Rattlesnake Hills-Wallula Gap Lineament pinches out against the Horse Heaven Hills structure; as the termination is approached, the folding becomes markedly tighter (see Cross Sections A through E). Most of the faults found in the Nine Canyon Map Area are related to folding; generally, they suggest the failure of basically brittle rocks along the hinge lines of the folds. However, not all of the faults are genetically reiated to folding; the Basalt Hill fault trends obliquely across the anticline implying the fault is younger.

The east-west-trending anticlinal ridges so characteristic of the western edge of the Columbia Plateau have traditionally been attributed to north-south compression. The east-west-trend of thesc ridgcs is interrupted as they enter the Pasco Basin; there, the trend of Umtanum Ridge, Yakima Hills, and Ratt.lesnake Ridge swings approximately 20 degrees to the south, where they are then coincident with the 0lympic-Wallowa. Lineament. Raisz (1945) postulated the 0lympic-Wallowa Lineament marked major structural features. Although the exact nature of the feature is uncertain, Dr. F. E. Goff reports sections along the lineament within the Pasco Basin that are coincident with zones of shearing, faulting, landsliding, and complex folding. 
Within the Nine Canyon Map Area, the Olympic-Wallowa Lineament is coincident with the Rattlesnake Hills-Wallula Gap Lineament; the youngest and most complex structure in the map area. Four en echelon, doubly plunging anticlines, locally faulted, are present. To the west, the faults are normal with small vertical displacement; to the east, they are reverse. Although evidence is inconclusive, this could suggest a sense of clock-wise rotation or right lateral movement. Dr. S. P. Reidel (1978) and Mr. K. R. Fecht (1978) indicate a possible zone of deformation extending northwest-southeast through the Saddle Mountains past the east end of Gable Mountain and down into Van Sycle Canyon east of Wallula Gap.

\section{BIBLIOGRAPHY}

ARH-ST-137, 1976, Staff, Research and Engineering Division, Preliminary Feasibility Study on Storage of Radioactive Wastes in Columbia River Basalts, Atlantic Richfield Hanford Company, Richland, Washington.

Bingham, J. W., Londquist, C. J., and Baltz, E. M., 1970, "Geologic Investigation of Faulting in the Hanford Region, Washington, " U. S. Geological Survey Open-File Report, 104 p.

Brown, R. E., 1968, A Study of Reported Faulting in the Pasco Basin, BNWL-662, Battelle, Pacific Northwest Laboratories, Richland, Washington.

Fecht, K. R., 1978, Geology of Gable Mountain-Gable Butte Area, RHO-BWI-LD-5, Rockwe 17 Hanford Operations, Richland, Washington, 59 p.

Gardner, J. N., 1977, "Stratigraphy and Faulting of Columbia River Basalt in Wallula Gap, Washington," abstract in EOS, American Geophysical Union Abstracts, 58 (12), p. 1247 .

Jones, F. 0., and Deacon, R. J., 1966, Geology and Tectonic History of the Hanford Area and its Relation to the Geology and Tectonic History of the State of Washington and the Active Seismic Zones of Western $r$ Washington and Western Montana, CA-0056, Douglas United Nuclear Industries, Inc., Richland, Washington.

Jones, M. G., and Fecht, K. R., 1977, "Exploratory Trenching Across the Wallula Gap Fault, South Central Washington, "abstract in EOS American Geophysical Union Abstracts, $\underline{58}$ (12), p. 1248.

Laval, W. N., 1956, Stratigraphy and Structural Geology of Portions of South-Central Washington, Ph.D. Thesis, University of Washington, Seattle, Washington, $223 \mathrm{p}$. 
Lillie, J. T., 1978, Near-Surface Geophysical Studies in the Western Half of the Pasco Basin, RHO-BWI-LD-13, Rockwell Hanford Operations, Richland, Washington.

Raisz, E., 1945, "The 0lympic-Wallowa Lineament," American Journal of Science, 243 A, p. 479

Reidel, S. P., 1978, Geology of the Saddle Mountains Between Sentinel Gap and 1190 and $30^{\prime}$ Longitude, RHO-BWI-LD-4, Rockwell Hanford Operations, Richland, Washington.

Schmincke, H. U., 1964, Petrology, Paleocurrents, and Stratigraphy of the Ellensburg Formation and Interbedded Yakima Basalt Flows, South-Central Washington, Ph.D. Dissertation, The Johns Hopk ins University, Baltimore, Maryland, $384 \mathrm{p}$.

Schmincke, H. U., 1967, "Stratigraphy and Petrography of Four Upper Yakima Basalt Flows in South-Central. Washington," Geological Society of America Bulletin, 78, p. 1385-1422.

Swanson, D. A., and Wright, T. L., 1976, "Guide to Field Trip Between Pasco and Pullman, Washington, Emphasizing Stratigraphy, Vent Areas, and Intracanyon Flows of Yakima Basalt," in Proceedings of the 72nd Annual Meeting of the Cordilleran Section, Geological Society of America at Pullman, Washington.

Swanson, D. A., Wright, T. L., Hooper, P. R., and Bentley, R. D., 1978, "Revisions in Stratigraphic Nomenclature of the Columbia River Basalt Group," U. S. Geological Survey Bullet in 1457, 92 p:

Waldron, H. H., and Bonilla, M. G., 1968, "Field Review of Possible Young Faulting in the Hanford Area, Washington," U. S. Geological Survey Open-File Report.

Wright, T. L., Grolier, M. J., and Swanson, D. A., 1973, "Chemic.al Variation Related to the Stratigraphy of the Columbia River Basalt," Geological Society of America Bulletin, 84 (2), 371-386.

Washington Public Power Supply System, Inc., 1977, Preliminary Safety Analys is Report, Volumes 1 and 2, Amendment 23, Richland, Washington.

\section{DISTRIBUTION}

Number of

Copies

J. F. T. AGAPITO 
Distribution (continued)

Number of

Pages

1 COLORADO SCHOOL OF MINES

1 J. W. CORWINE

1 GEOSCIENCE RESEARCH CONSULTANTS

J. G. Bond

IDAHO BUREAU OF MINES AND GEOLOGY

M. M. Miller

OREGON STATE DEPARTMENT OF GEOLOGY AND MINERAL INDUSTRIES

J. D. Beaulieu

1

OREGON STATE UNIVERSITY

Department of Geology

1

PACIFIC NORTHWEST LABORATORY

J. R. Raymond

F. L. PARKER

I. REMSON

1

R. SCHNEIDER

G. SERVOS

U. S. BUREAU OF RECLAMATION Columbia Basin Project Geologist

1

U. S. DEPARTMENT OF ENERGY-COLUMBUS PROGRAM OFFICE

J. Neff

2

U. S. DEPARTMENT OF ENERGY-HEADQUARTERS

M. W. Frei

D. L. Vieth

U. S. DEPARTMENT OF ENERGY-RICHLAND OPERATIONS OFFICE

R. B. Goranson

D. J. Squires (2)

1 U. S. GEOLOGICAL SURVEY-WATER RESOURCES DIVISION

C. Collier

1 U. S. GEOLOGICAL SURVEY-WESTERN DIVISION

D. A. Swanson

1 UNIVERSITY OF IDAHO

Department of Geology 
Distribution (continued)

Number of Pages

UNIVERSITY OF WASHINGTON

Department of Geology

1

WASHINGTON PUBLIC POWER SUPPLY SYSTEM, INC.

D. D. Tillson

1

WASHINGTON STATE DEPARTMENT OF ECOLOGY

P. M. Grimstad

1

WASHINGTON STATE DEPARTMENT OF NATURAL RESOIIRCES

V. E. Livingston.

1

WASHINGTON STATE UNIVERSITY

Department of Geology

1

A. C. WATERS

1

H. C. WEI SENECK

1

WESTERN WASHINGTON UNIVERSITY

Department of Geology

39

ROCKWELL HANFORD OPERATIONS

H. Babad

D. J. Brown

D. J. Cockeram

T. A. Curran (5)

R. A. Deju (2)

R. C. Edwards

R. E. Gephart

R. J. Gimera

R. E. Isaacson

C. W. Myers

W. H. Price (5)

Basalt Waste Isolation Program Library (15)

Document Control (4) 


\section{APPENDIX}

\section{MEASURED SECTION NUMBER 1: THE BUTTE}

Section 3, Township 17 North, Range 30 East

Figure $A-1$

\section{INTERVAL 1}

A ledge of large stubby columns ( 1 to 2 meters across) tops the section. These Ice Harbor I (basalt of Martindale) columns have a platey vesicularity and reddish brown color on weathered surfaces. The fresh rock is dark gray, medium- to coarse-grained, and diktytaxitic. Unlike the Ice Harbor in other localities, this exposure is only sparsely plagioclase-phyric. About 6.5 meters down slope, the columns lose their vesicularity and appear denser, exhibiting spheroidal weathering where exposed. Sample C-7338 (Table I) is from the top ledge of columns. This unit has reversed natural remanent magnetism.

Interval Thickness: 10.3 meters.

\section{INTERVAL 2}

This break in slope marks the approximate. Ice Harbor-Elephant Mountain contact. The interval is covered with vesicular rubble down to about 12.5 meters (total thickness) where a ledge of small columns $(0.4$ meter across) marks the base of this interval. These gray-brown columns are the upper colonnade of the Elephant Mountain Member. Sample C-7339 (Table I) is from these small columns. The rock is very vesicular and grayish-green due to extensive alteration. In hand specimen, it is aphyric, fine- to medium-grained, and exhibits a hackly fracture.

Interval Thickness: 2.5 meters.

\section{INTERVALS 3 AND 4}

The gently sloping topography is covered with vegetation, pebble-sized glaciofluvial exotics, and fist-sized pieces of vesicular and grussic weathered basalt. The separation of this section into two 
intervals is based on a change in slope--probably the Elephant Mountain entablature--colonnade juncture. (Throughout the Nine Canyon Map Area, the Elephant Mountain is a slope-former, rather than a cliff-former-presumably due to its porous texture which provides easy access to alteration.)

Interval Thickness: 19.9 meters.

\section{INTERVAL 5}

This break in slope is the approximate contact between the Elephant Mountain and Pomona flows. The bench is covered with vesicular float and glaciofluvial pebbles (quartzite, slates, chert). This, and vegetation, effectively conceals the contact and any Rattlesnake Ridge Interbed that may be present. A ledge of gray-brown columns approximately 0.3 meter across marks the base of this interval. Sample C-7340 (Table I) was Laken liere.

Interval Thickness: 4.6 meters.

\section{INTERVAL 6}

Although much of the upper portion of this interval is covered, isolated outcrops with smal1, well-formed, broken columns demonstrate that this is Pomona entablature. In hand specimen, the rock is dark gray, medium- to fine-grained and plagioclase phyric. Plagioclase phenocrysts to 2 centimeters and occasional olivine phenocrysts less than 1 centimeter are discernible. Approximately 15 meters down begin larger columns about 1 meter across. Sample $C-7341$ (Table I) is from the base of Interval 6.

Interval Thickness: 19.2 meters.

\section{INTERVAL 7}

This narrow bench marks the approximate top of the Umatilla Member-bright red, vesicular Umatilla float can be found down slope from here, 
a)though the contact itself is not exposed at this location. No Selah Interbed is present, although it is present one-quarter mile northwest in Finley Quarry.

Interval Thickness: 3 meters.

INTERVALS 8 AND 9

Again, these intervals are separated on the basis of a change in slope. Interval 8 is largely covered by a mixture of float from above, mingled with Umatilla float; however, irregular hackly outcrop protrudes through the cover. Weathered surfaces are orange and red; fresh Umatilla is black, very glassy, and aphyric. Interval 9 consists of Umatilla entablature-forming hackly cliffs. Sample C-7342 (Table I) is from the upper portion of Interval 9.

Interval Thickness: 22.7 meters.

TOTAL THICKNESS: 82.2 meters. 


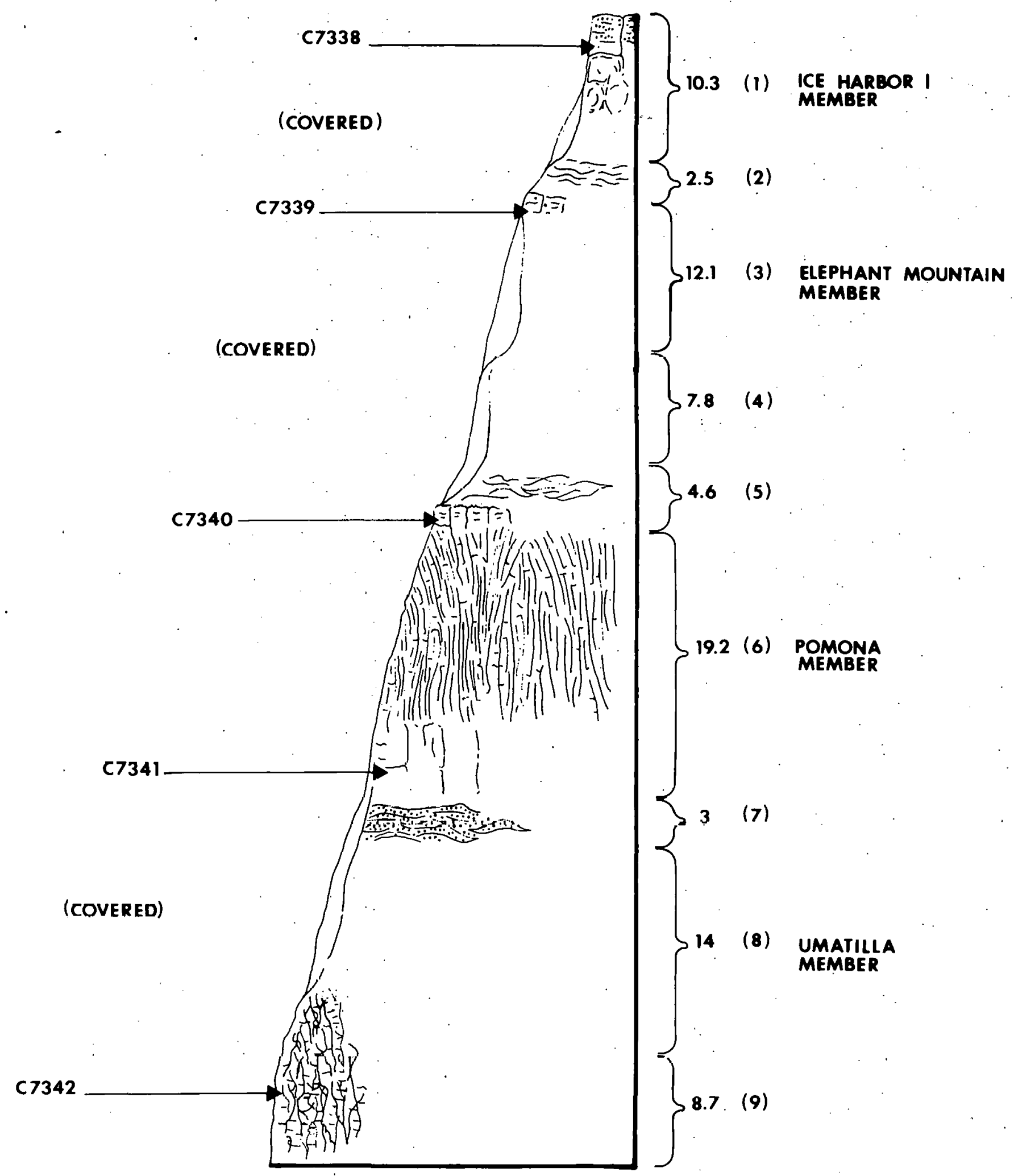

FIGURE A-1

MEASURED SECTION - THE BUTTE

( 2.54 centimeters $=10$ meters; horizontal not to scale.) 


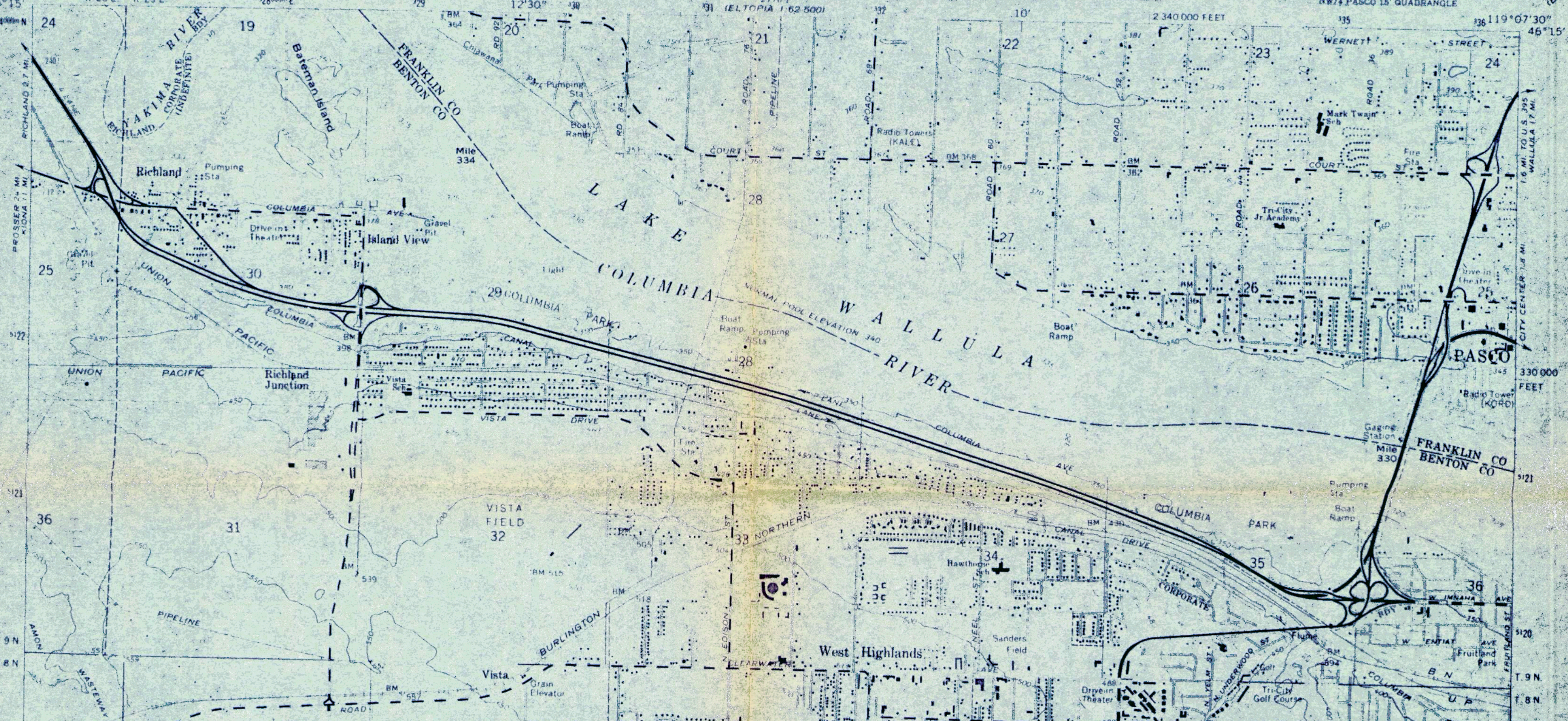

WI,

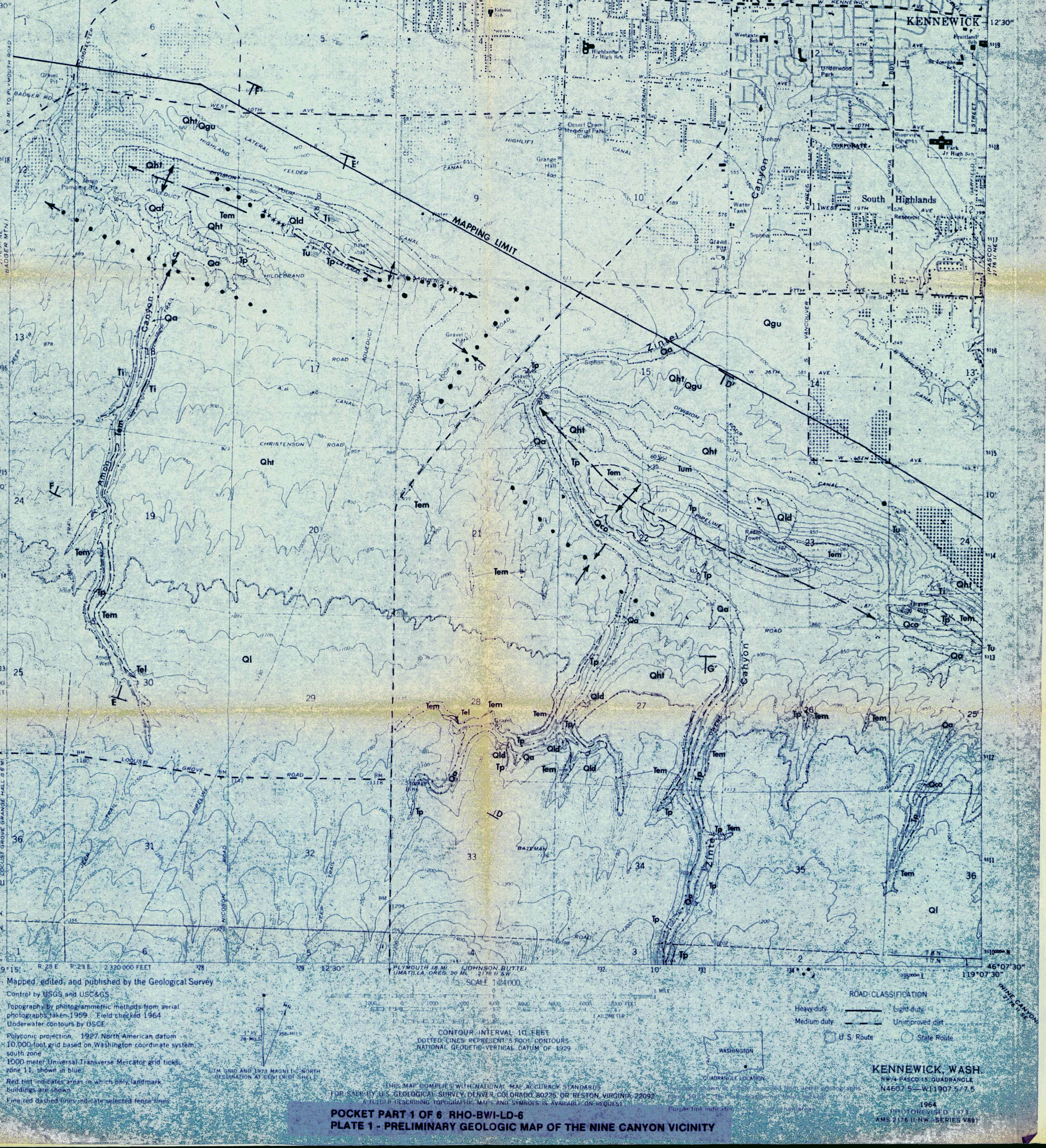




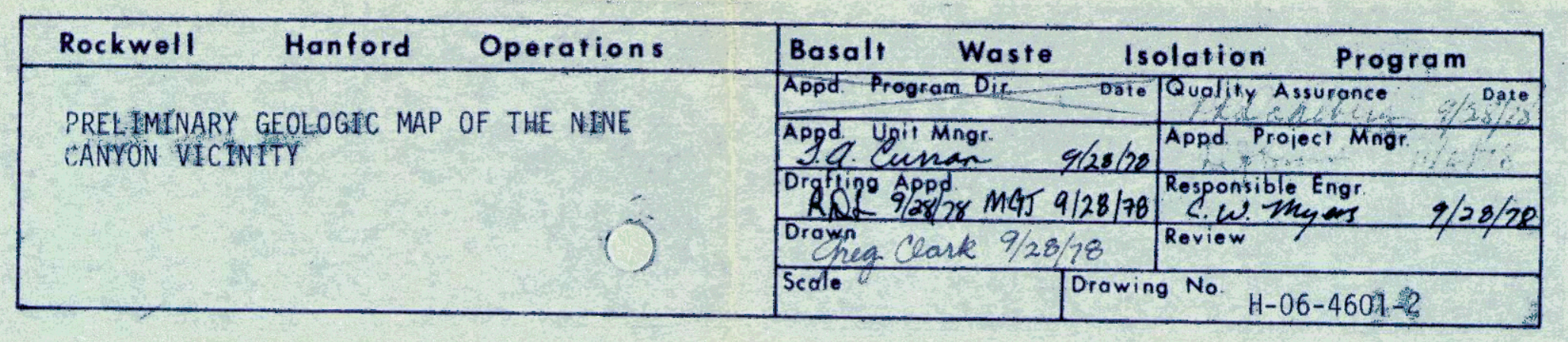

PASCO QUADRANGLE

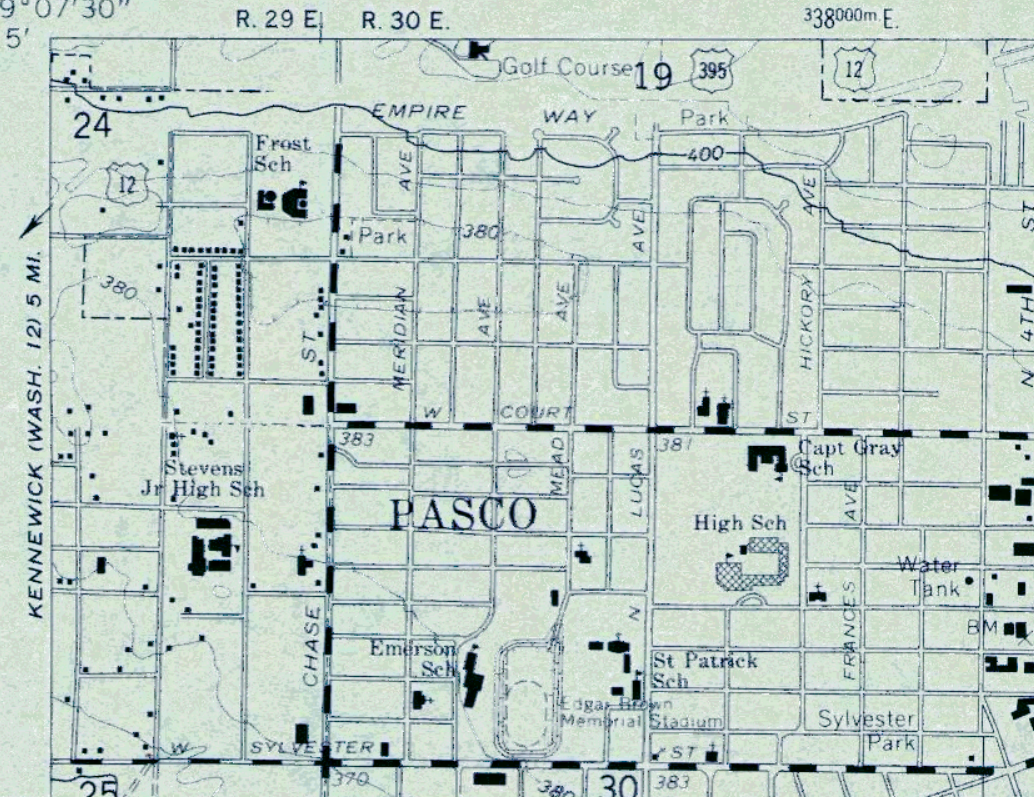
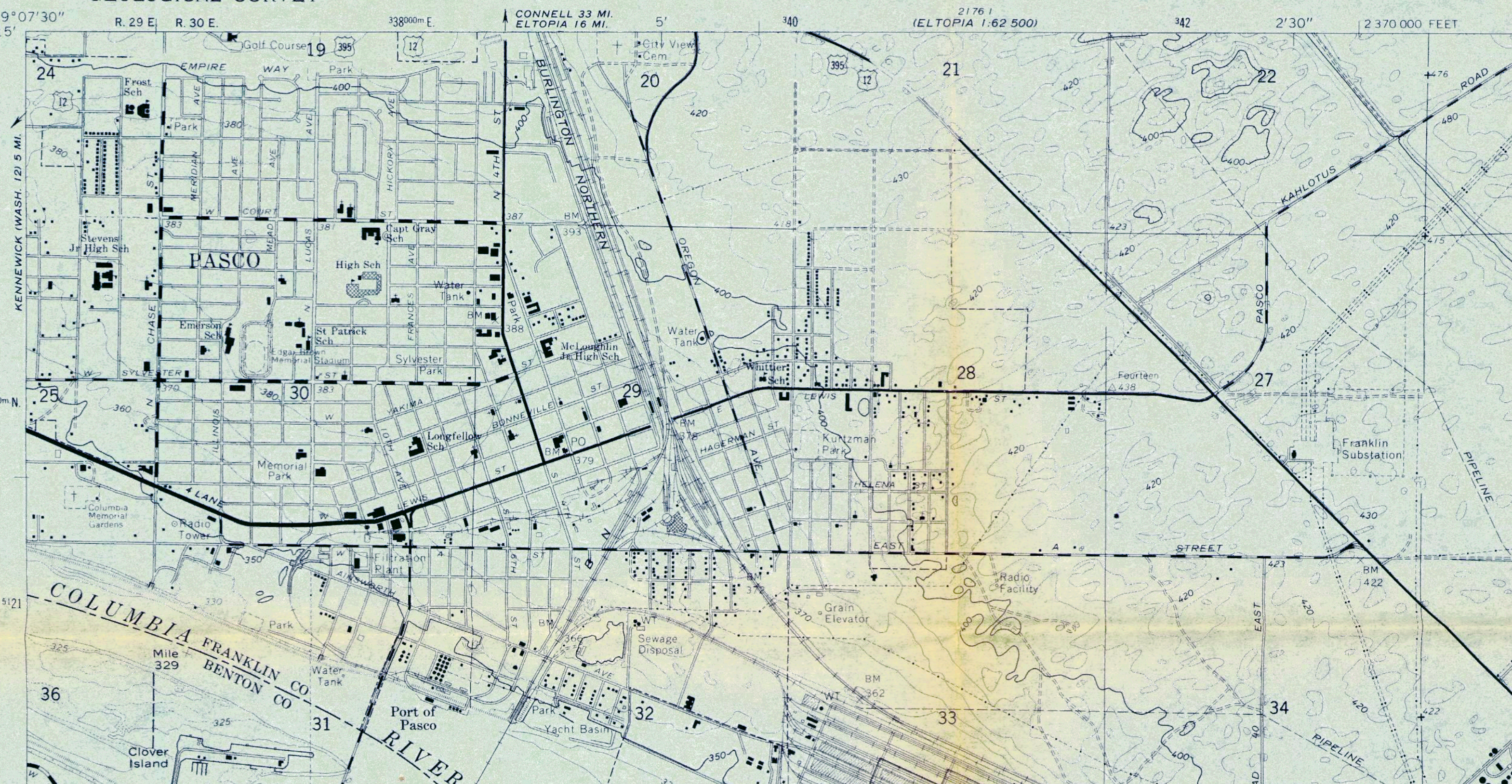

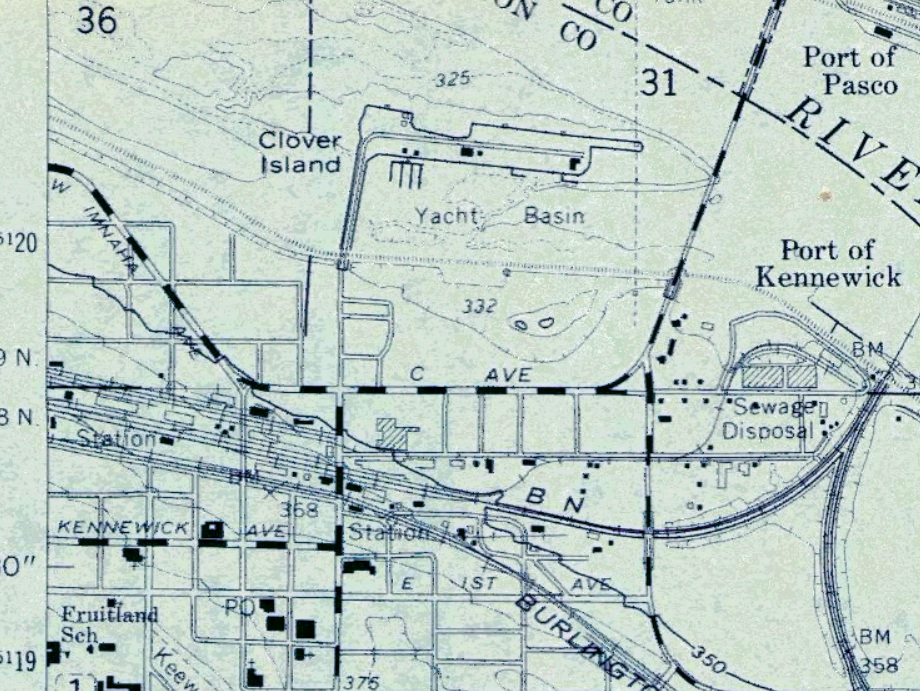

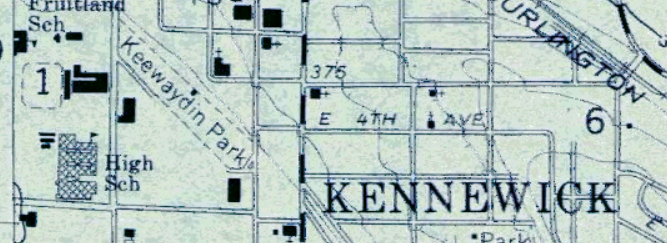

$[i+i-1+i$

(1)
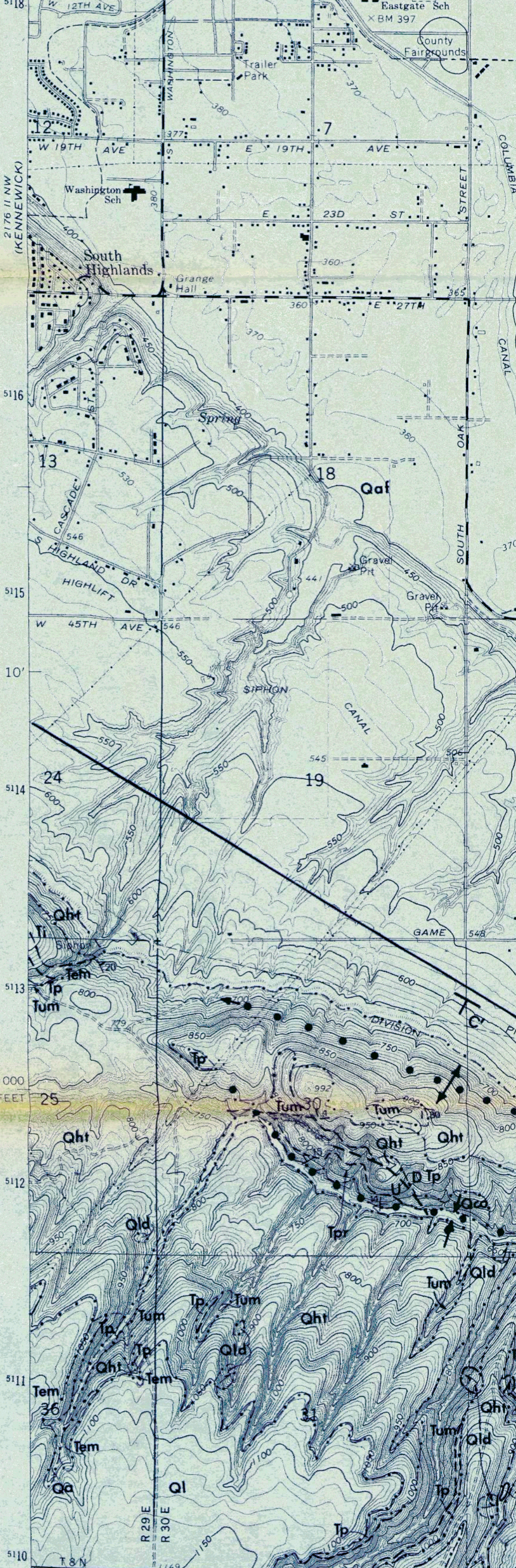

Mapped, edited, and published by the Geological Survey

Control by USGS. USCrGS, and U.S. Bureau of Reclamation

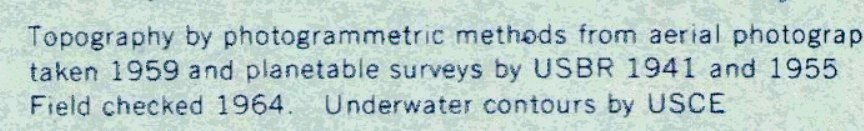

Selected hydrographic data compied from USC 6 GS
Charts 6164 (1960) and 682-SC (1963)
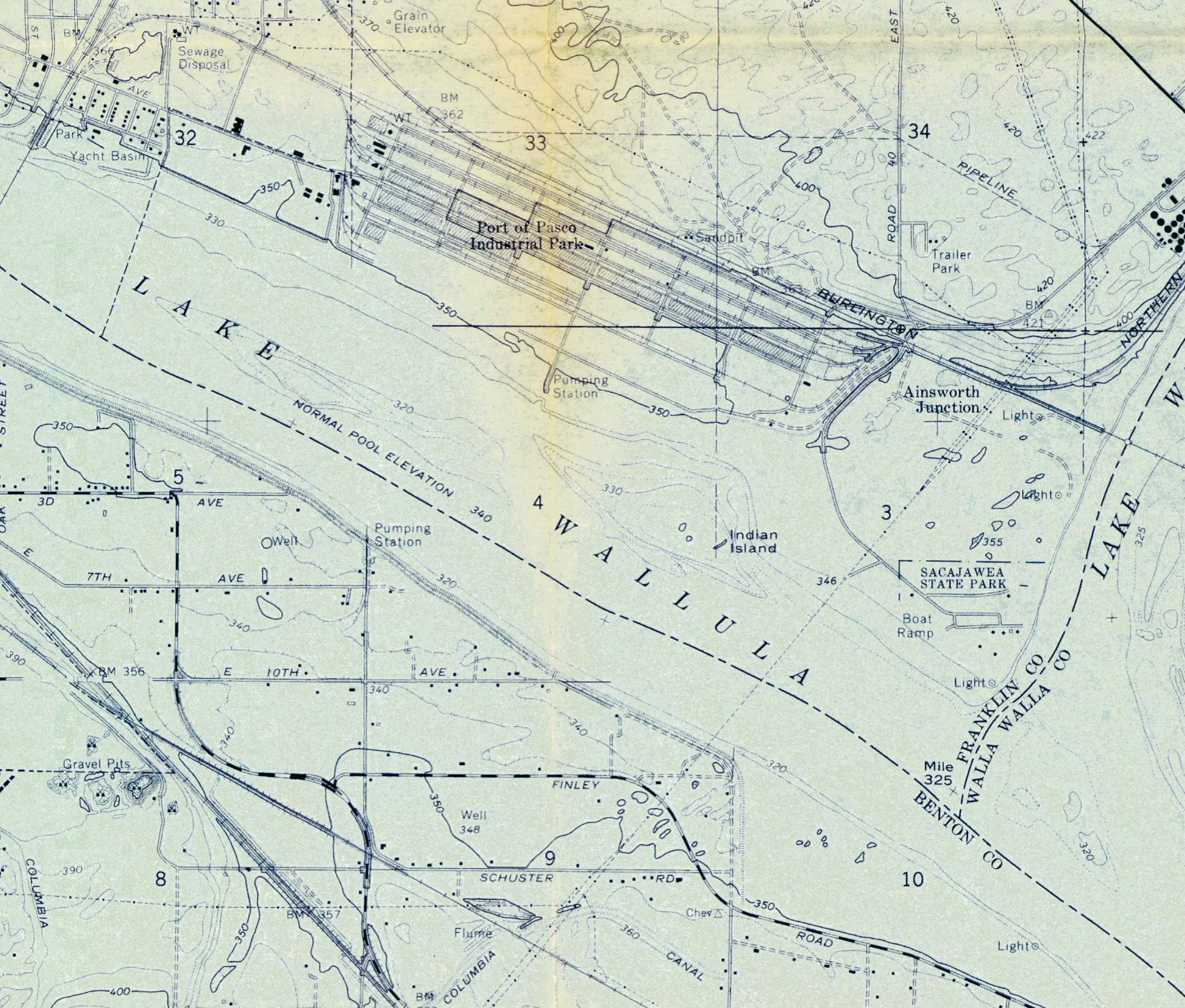


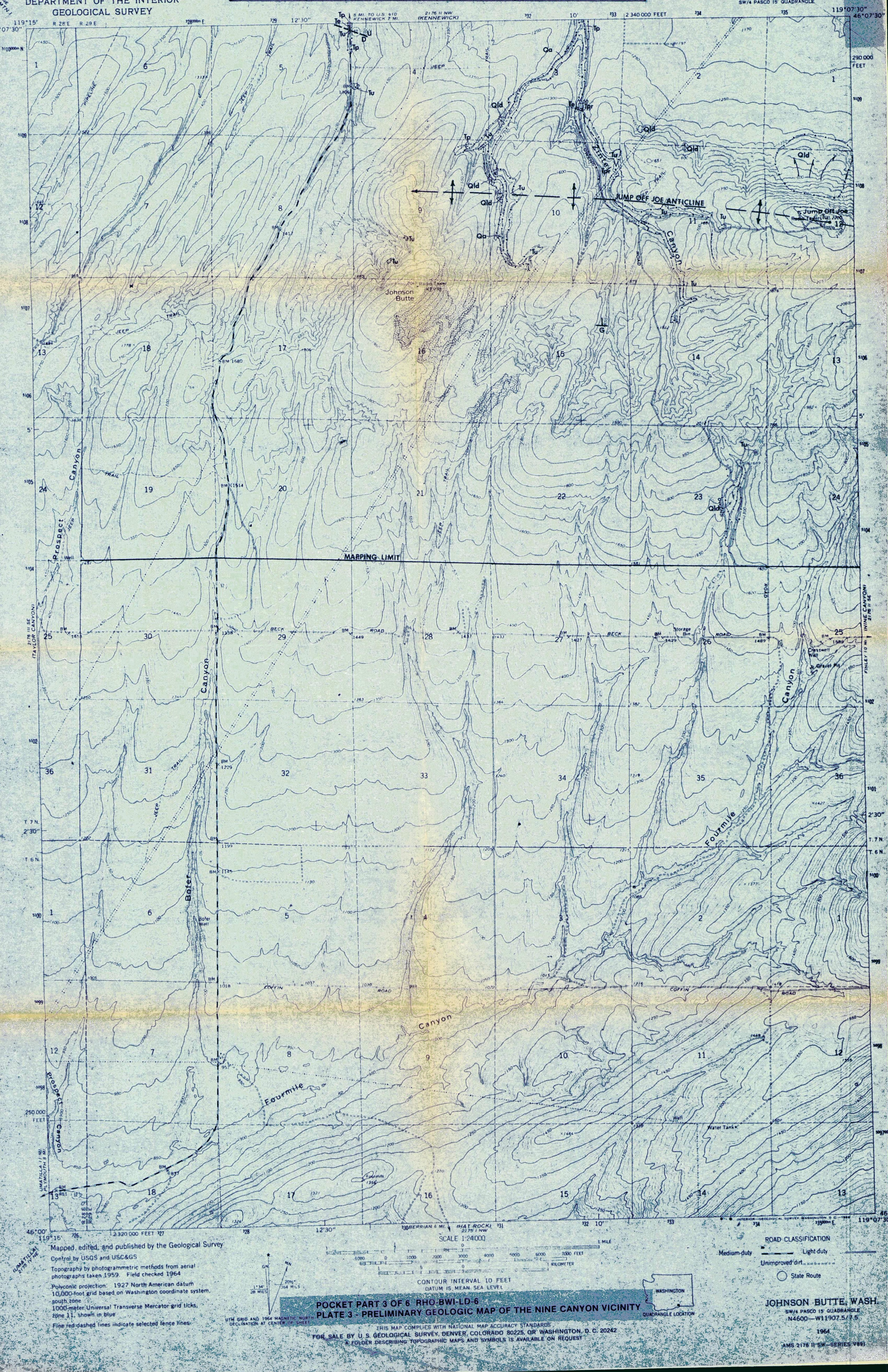




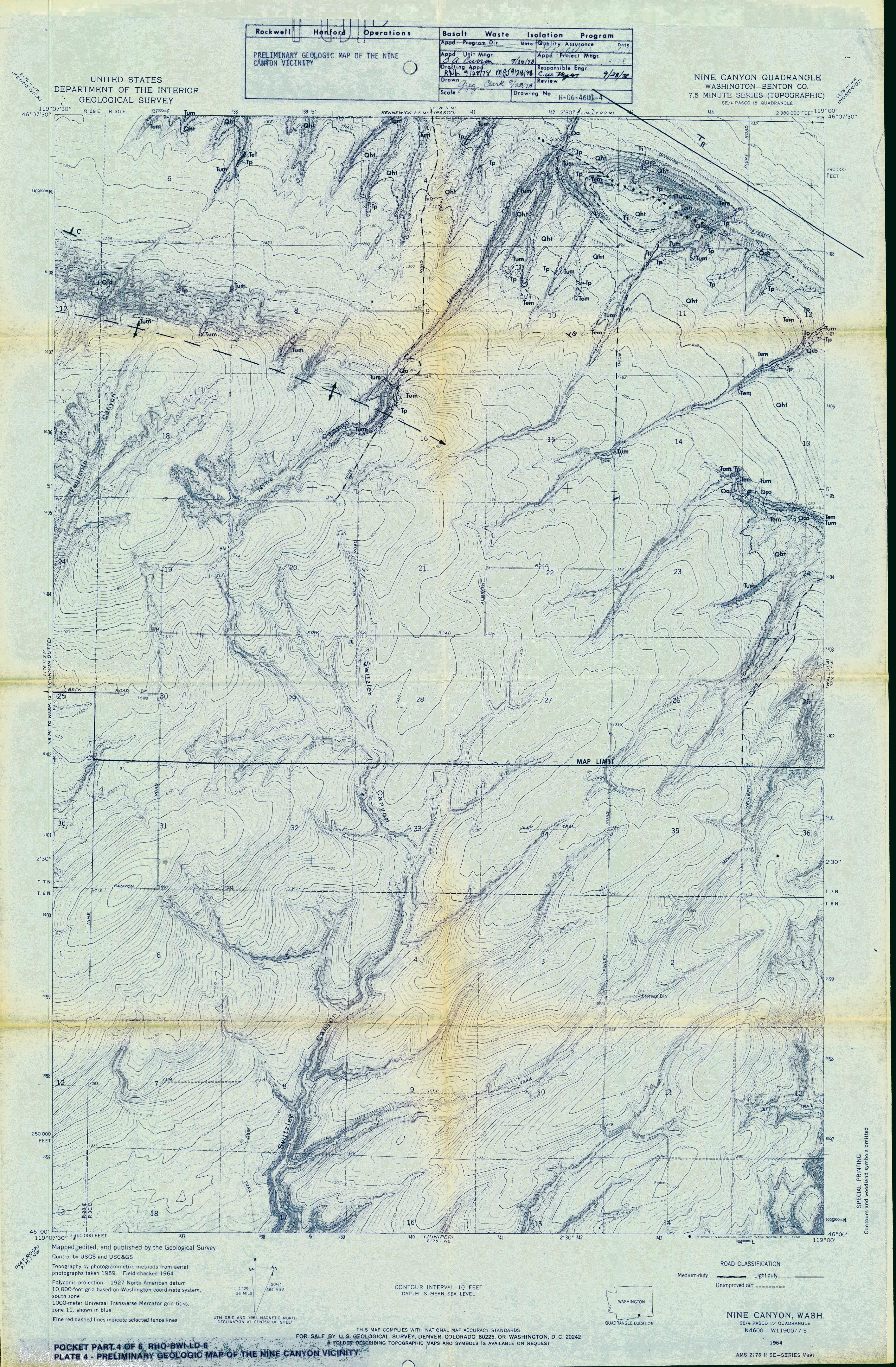



